\title{
Yapıların Zaman-Frekans Ortamında Dalgacık Dönüşümü Metoduyla Hasar Analizleri
}

\author{
Ömer Fatih SAK ${ }^{1}$ \\ Kemal BEYEN ${ }^{2}$
}

Öz

Bu çalışmada zaman-frekans ortamında uygulanan hasar tanılama tekniklerinde gözlenen son araştırmalara bakılarak yeni hasar tanılama algoritmaları incelenmiştir. Özellikle yapı sağlığı çalışmalarında ivme, hız ve deplasman gibi kinematik parametreleri ve bunların türevleri üzerinden örneğin hız bilgisinin enerji tabanlı kinetik bir parametre ile ifade edilerek etkin hasar tespitleri yapılabildiği bilinmektedir. Analitik modellerden elde edilen sitasyoner ve ergodik yapıda olmayan kinematik ölçümlere dalgacık dönüşümleri uygulanarak hasar alan ve doğrusal olmayan özellik gösteren yapısal elemanlar tespit edilmiştir. Sürekli dalgacık dönüşümü ve dalgacık paket dönüşümü uygulanan örneklerde bu metotların hasar tespitinde etkili bir yöntem olarak kullanılabileceği sonucuna ulaşılmıştır.

Anahtar Kelimeler: Yapı sağlığı, dalgacık dönüşümleri, hasar tanılama.

\section{ABSTRACT \\ Damage Analysis of the Structures in Time-Frequency Domain with Wavelet Transform Method}

In this study, newly improved damage detection algorithms of the recent researches have been investigated in time-frequency domain analysis. It is known that effective damage assessment can be made on accelerations, velocities and displacements as kinematic information and the derived energy consumption through dynamic behavior of a structural system in view of structural health studies. The wavelet transforms are applied to the kinematic parameters inferred from analytical models which do not have stationary and ergodic characteristics and results are used to determine the damage potentials of the structural members and nonlinearity if exist. Cases in which the continuous wavelet transform and wavelet packet transform are applied show great potential for an effective damage detection. It is believed that these methods should be used in a complementary way to effectively and correctly assess the health condition of an engineering structure.

Keywords: Structural health, wavelet transforms, damage identification.

\footnotetext{
Not: Bu yaz1

- Yayın Kurulu’na 17 Mart 2017 günü ulaşmıştır. 17 Nisan 2018 günü yayımlanmak üzere kabul edilmiștir.

- 31 Mart 2019 gününe kadar tartışmaya açıktır.

- DOI: $10.18400 /$ tekderg.300366
}

1 Kocaeli Üniversitesi, İnşaat Mühendisliği Bölümü, Kocaeli - omerfatihsak@gmail.com

2 Kocaeli Üniversitesi, İnşaat Mühendisliği Bölümü, Kocaeli - kbeyen@kocaeli.edu.tr 


\section{GíRiş}

Doğal afetler arasında deprem en yıkıcılarındandır. Toplumsal krizlerin ötesinde yüksek seviyede can ve mal kaybına sebebiyet vermektedir. Örneğin 1994'de Amerika Los Angeles depremi sonucunda 61 can kaybı ve 40 Milyar dolar kayıp yaşanmıştır. 1995 yılında Japonya Kobe depreminde 6.400 can kaybı ve 100 Milyar dolar kaybedilmiştir. 1999 Türkiye Kocaeli depreminde 18.373 can kaybı ve 20 Milyar dolar kaybedilmiştir. 1999 senesinde Çin'in Tayvan şehrinde 2.300 can kaybı ve 9 Milyar dolar mal kaybı olmuştur. Son olarak 2011 Van depreminde 644 vatandaşımız hayatını kaybetmiştir. Bu sonuçları mühendislik disiplinleri bağlamında değerlendirdiğimiz takdirde can ve mal kayıplarının depremden ziyade depreme dayanıksız yapılardan kaynaklandığg görülmektedir. Bu sebeple zararı depremin değil gerekli dayanıma sahip olmayan binaların verdiği bir gerçektir. Sonuç olarak binaların imal edilmeden önce depreme karşı yüksek performans sergilemesi ve imalat aşamalarının denetlenmesi gerekmektedir. Bunun neticesinde kritik öneme sahip, insanların yoğun olarak kullandığı ve belirli yüksekliğe sahip binaların da anlık olarak izlenmesi ve yapısal performanslarının düzenli olarak takip edilmesi ihtiyacı doğmuştur.

Bu nedenle akıllı binalar olarak tanımlanan, hareket sensörleriyle yapı sağlığının anlık olarak izlendiği ve olası deprem karşısında hasarın hangi bölgede ve mertebede olduğunu tespit edebilen sistemler geliştirilmiştir. Bu sistemlerde hasarı tanılamak için faydalanılan temel prensip yapısal elemanlarda oluşabilecek hasarların ve rijitlik kayıplarının yapıdaki frekans, mod şekli gibi parametrelerini değiştirmesidir. Tespit edilmek istenen modal parametreler gürültü, ortam kaydı ya da deprem kaydıyla belirlenebilmektedir. Titreşim parametrelerine bağlı olarak hasar tanılama metotları dört ana kategoride değerlendirilmektedir. Bunlar; doğal frekansa bağlı metotlar, mod şekline bağlı metotlar, mod şekli eğriliğine bağlı metotlar ve mod şekilleri ile frekansları birlikte kullanan metotlardır.

Araştırma ve yeni metotlar belirlemede basit yapılara odaklanmak için iki ana sebep bulunmaktadır. Bunlardan birisi çoğu yapının kiriş veya plakalardan meydana gelmesidir. Bir diğer sebebi ise kiriş ya da plakalarda belirli bir hasarın tanımlanmasıyla tanılama tekniklerinde önemli kriterlere ulaşılabilmektedir. Özelde daha basit bir şekilde ispatlanan bu metotlar genel ve büyük yapılara da kolaylıkla uygulanabilmektedir. Son yıllarda sensör maliyetleri teknolojinin de gelişmesiyle birlikte yaygın olarak uygulanabilir hale gelmiştir. Bundan otuz sene öncesinde bir yapı üzerinde sadece üç adet ivmeölçer kullanılmakta ve yeterli görülmekteydi. Şimdi ise maliyetlerinin düşmesiyle birlikte tek bir yapı üzerinde yüzlerce sensör yerleştirilebilmektedir.

\section{GEÇMIŞ ÇALIŞMALAR}

Araştırmacıların bir çoğu yapı sağlığı izleme sistemlerini anomali tespiti bağlamında tanımlamışlardır. Bunlar zaman-frekans çözünürlüklerindeki tepe noktaları, ani sivriltiler, skalogramdaki düzensizlikler, enerji katsayılarındaki farklılıklar ve eşikleme parametreleri olabilmektedir.

Deng ve Wang [1] kirişlerde hasarın oluşumu ve konumunu belirleme oranını uzamsal dalgacık dönüşümünü kullanarak araştırmıştır. Sabit yükler altında basit mesnetli kirişi ve dinamik darbe yükü altında konsol kirişi Haar dalgacık dönüşümünü kullanarak tepki sinyalini analiz etmişlerdir. Worden ve Dulei-Barton [2] tarafindan tanımlanan yapısal sağlık 
izleme sistemlerinin yapıları dalgacık dönüşümlerinin özellikleri sayesinde sinyalin zaman ve frekans çözünürlüklerini iyi bir şekilde sağlamaktadır. Böylece yeniden düzenlenen izleme yapısı araştırmacıları dalgacık dönüşümlerini hasar tespiti ile ilgili özellikleri teşhis etmek için motive etmiştir. Patsias ve Staszewski [3] dalgacık dönüşümlerinin kullanarak optik olarak gözlenen mod şekillerinden hasar tespiti yapılabildiğini göstermişlerdir. Mod şekillerinin dalgacık dönüşümlerinden yardımcı bilgi üretilmiş ve mod şekil değiştirmeleri yaklaşım sinyallerinden elde edilmiştir. Detay sinyallerinden ise hasar konumu hakkında bilgiye ulaşılmıştır. Hasar tespiti dalgacık skalogramındaki sinyal enerjisi gözlemlenerek gerçekleştirilebilmektedir. Yan ve Yam [4] enerji spektrumu ve dalgacık paket analizi metodunu bir indis vektörü ile kullanarak küçük yapısal hasarları tespit etmiştir. Belirli bir dalgacık ayrıştırma seviyesinde indis vektörünün en büyük değeri hasarlı moda bağlı olarak hasarı göstermektedir. Son olarak hasarın konumu ve derecesi kompozit bir yapıda tanımlanmıştır. Mallat [5] tarafından dalgacık dönüşümlerinde kullanılmak üzere iki tür dalgacık fonksiyonu tarif edilmiştir. Bunlar gerçek ve analitik dalgacıklardır. Gerçek dalgacıklar sert sinyal geçişlerini algılamak için, analitik dalgacıklar ise anlık frekans değişimini tanımlamak için kullanılmaktadır. Bir dalgacığın tüm negatif frekansları için Fourier dönüşümü sıfıra eşit ise analitik dalgacık olarak adlandırılmaktadır. Liew ve Wang [6] yapısal sistemlerdeki yayılmayan çatlak tespiti için dalgacık dönüşümünün özdeğer analizinden daha etkili olduğunu göstermişlerdir. Park ve diğ. [7] laboratuvar ortamında modellenen ve 300 eleman ve 91 düğüm noktasından oluşan uzay kafes sistemi modal uzama enerjisi metoduyla analiz etmiştir. Bu metotla frekans kaydırma yöntemlerinin aksine şiddetli hasar senaryoları zayıf hasar senaryolarına nazaran daha iyi tanımlanmıştır. Bu durumun deneysel verilerdeki gürültünün maskeleme etkisine bağli olduğu sonucuna ulaşılmıştır. Douka ve diğ. [8] temel titreşim modunun sürekli dalgacık dönüşümünü kullanarak kiriş üzerindeki çatlağın konumu ve büyüklüğünü belirlemiştir. Benzer bir çalışma Gentile ve Messina [9] tarafından yapılmıştır. Sürekli dalgacık dönüşümünün çatlak konumu ve büyüklüğünün gürültülü ve temiz data üzerinden tespit edebildiğini göstermişlerdir.

Zaman tanım alanındaki titreşimlerden hasar tanılamaları yapan, mod şekli ve frekans gibi modal parametrelerin elde edildiği akıllı binalarda (Xu ve diğ. [10]) deprem sonrası durum tespiti amaçlanmaktadır. Chang ve Chen [11] çok çatlaklı kirişte hasar tespiti için uzaysal Gabor dalgacık tabanlı tekniği sunmuştur. Doğal frekanslar ve çatlak pozisyonları göz önüne alındığında, çatlak derinlikleri geleneksel karakteristikte denklemlere dayanan bir optimizasyon işlemiyle çözülmüştür. Analiz ve karşılaştırmalar bu metodun çatlak pozisyonunu ve derinliğini tespit edebildiğini ve tutarlılığının da iyi seviyede olduğunu göstermiştir. Chang ve Chen [12] bu tekniği dikdörtgen biçiminde bir plakaya da uygulamışlardır. Kim ve diğ. [13] kiriş benzeri yapılar için dalgacık dönüşümü kullanarak mod şekli eğriliğine dayalı hasar tanılama metodu önermiştir. Bu çalışmada küçük bir hasar varsayımı ve Haar dalgacık dönüşümü kullanarak bir dizi doğrusal cebrik denklemler hasar mekanizmasına bağlı olarak verilmiştir. Poudel ve diğ. [14] kiriş tipi yapılarda mod şekli farklılığının kompleks Gaussian dalgacık dönüşümüne dayalı olan bir hasar tespit metodu önermiştir. Gaussian dalgacığı, kompleks Gaussian dalgacığı ve Morlet dalgacığı olmak üzere üç farklı dalgacık dönüşümleri bu çalışmada karşılaştırılmıştır.

Dalgacık paket dönüşümü (WPT) hasar tanılama metodu olarak inşaat, uzay ve makine mühendisliği gibi birçok alanda çalışılmıştır. Sami ve diğg. [15] dalgacık paket enerji bileşenlerini sinirsel ağlar modeline bir girdi olarak tanımlayarak hasar tespitinde 
kullanmışlardır ve bu metodun hasar tanılamada kullanışlı olduğu sonucuna ulaşmışlardır. Zhong ve Oyadiji [16] sürekli dalgacık dönüşümüne yeni bir yaklaşım önermiştir. Çatlamış basit mesnetli bir kirişin mod şekillerinin iki data seti üzerinden çalışma yapmışlardır. Sonuç olarak orijinal mod şekil verisinin sürekli dalgacık dönüşüm sonuçlarından daha iyi bir çatlak göstergesi elde etmişlerdir. Analitik ve deneysel sonuçlar önerilen yöntemin çatlak tespiti için çatlak olmayan kirişin modal parametrelerini gerektiren çatlak tespit metotlarına göre üstünlüğünü göstermiştir. Beyen [17] dalgacık spektrumlarının yapı sağlığı durum değerlendirme çalışmalarında önemi hakkında çalışmıştır. Bu araştırmada hareket noktasını oluşturan dalgacık güç spektrumu özellikleri, istatistiki tutarlılık ve çapraz korelasyon uygulamalarının yapı sağlığı çalışmalarında elde edilecek sonuçları güçlendirdiğini gösterilmiştir. Beata ve diğ. [18] yapı üzerinde ilerleyen dalgalar üzerinden hasar tanılama çalışması yapmıştır. Yansıyan dalgaların enerjilerinin düşük olmasından hasarı tanımlamanın güçleşmesi neticesinde dalgacık analizleri kullanılmıştır. Hasar sonrasında oluşan yansıma dalgaları üzerinden tanılamayı gerçekleştirmek için Morlet dalgacıklarına dayalı sürekli dalgacık dönüşümü skalogramlarına bakılmıştır. Wang ve diğ. [19] dalgacık paket bileşenlerinin enerjileri üzerinden hasar tespiti ve konumunu belirlemek için modifiye dalgacık paket enerji derecesini (MWPER) geliştirmişlerdir. Bir deneysel çalışma üzerinden dalgacık paket enerji derecesi (WPER), MWPER ve uzama zaman eğrisinin zarf alanı (EASC) metotlarını kıyaslamışlardır. Sonuç olarak küçük hasarlarda MWPER metodunun diğer iki metoda göre daha duyarlı olduğunu göstermişlerdir. Kaloop ve diğ. [20] analitik bir model üzerinden Daubhecies (DB10) dalgacığını kullanarak sürekli dalgacığın toplam enerjisi ve ayrık dalgacığın dağılımları üzerinden mukayeseli olarak hasar tanılama çalışması yapmıştır. Sonuç olarak ayrık metodun sürekli olana göre daha belirgin olduğu ve hasar tespiti için daha uygun olduğu sonucuna ulaşmıştır. Sonuçların saha ölçümlerinden elde edilen veriler üzerinden deneysel olarak da çalışılması gerektiği belirtilmiştir. Kareem ve diğ. [21] doğrusal olmayan sinyal karakterizasyonunun sürekli dalgacık dönüşümü ve ampirik mod ayrışımıyla Hilbert dönüşümünü incelemiştir. Kareem ve diğg. [22] bir başka çalışmasında sürekli dalgacık dönüşümü ile Hilbert Huang dönüşümünün gürültü altındaki anlık frekans tahminlerinin performanslarını değerlendirmiştir. Sonuç olarak gürültü seviyesi arttıkça HHD'nin ampirik temellerden sinyal çıkarma ve yeniden yapılandırma süreçlerinin problemli olduğu ve dalgacık dönüşümünün bu tür analizler için daha güvenilir bir alternatif sağladığı belirtilmiştir.

\section{YAPILARIN DAVRANIŞI VE ZAMAN-FREKANS ALANINDA HASAR TANILAMA}

Yapıların tasarımında ve inşaat sonrası yapı izleme metotlarında temel alınan en önemli faktörlerden birisi yapının deprem karşısındaki davranışı ve hasar görebilirlik mertebesidir. Farklı amaçlarla kullanılacak yapılarda hasar mertebeleri sınırlandırılmaktadır ve yapıların tamamının can güvenliğini sağlayacağı öngörülmektedir. Hasar anomalisini tespit edebilmek için zaman-frekans çözünürlüğünde yaygın olarak dalgacık dönüşümleri kullanılmaktadır. Dalgacık sınırılı süreli olan; ortalaması, başlangıç ve bitiş değeri sıfır olan dalga formlarına denilmektedir. Dalgacıklar düzensiz, sınırlı süreli ve asimetrik olduğundan anomali, titreşim ve sinyal içindeki olayları iyi tanımlamaktadırlar.

Dalgacık dönüşümleri kısa süreli fourier dönüşümlerine (STFT) göre bir takım farklara ve avantajlara sahiptir. Bilindiği gibi kısa süreli fourier dönüşümleri de zaman frekans 
çözünürlüğü vermektedir ancak dalgacık dönüşümlerinden elde edilen çözünürlüklerde sabit bir şekil bulunmamaktadır. Düşük frekanslarda daha iyi frekans çözünürlüğü, yüksek frekanslarda ise daha iyi zaman çözünürlüğü vermektedir. Bu değişken çözünürlük bazı belirli sinyallerde düşük ve yüksek frekansların aynı anda zaman-frekans alanında birleştirilerek görülmesinde avantaj sağlamaktadır.
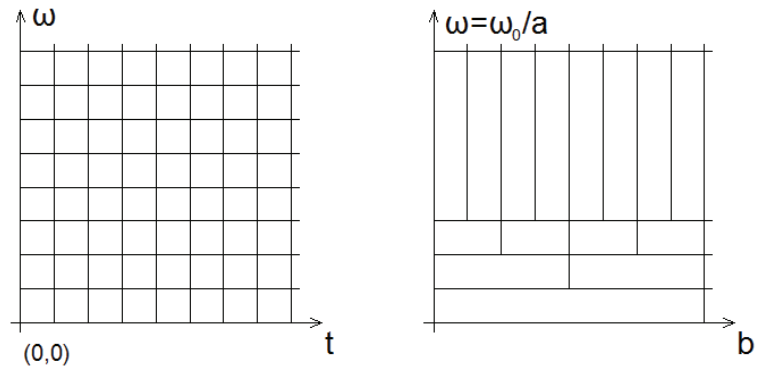

\section{Şekil 1 - Kısa Zamanlı Fourier Dönüşümü ile Dalgacık Dönüşümünün Zaman Frekans Alanindaki Mukayesesi}

Dalgacık analizine dayalı hasar tespit teknikleri iki farklı yaklaşıma dayanmaktadır. Bunlardan birincisi ayrık dalgacık dönüşümleridir. Bunlar sinyaldeki yaklaşım ve detay seviyelerindeki ani değişimleri tespit ederler. Detay ayrışımındaki ani sıçramalar yapısal hasarla ilişkili olabilmektedir. İkinci yaklşım olarak sürekli dalgacık dönüşümleri tepki sinyalinin zaman frekans haritasını oluşturarak yapının doğal frekansındaki değişimleri tespit etmektedir. Genel olarak sürekli dalgacık dönüşümleri zaman-frekans analizleri için daha iyi olmakla birlikte ayrık dalgacıklar ayrıştırma, sıkıştırma ve özellik belirlemek için daha uygundur. Ancak dalgacık seçimi her zaman açık değildir. Grossman ve Morlet dalgacıkları en iyi bilinen sürekli dalgacıklardır. Daubechies dalgacıkları bilinen en iyi ortogonal dalgacıklardır. Biortogonal dalgacıklar (örn. Dual B-Dalgacıkları) ayrık dalgacıkların özel durumlarında kullanılır ve iki dalgacık setinden oluşur. Bunlardan birisi ayrıştırma diğeri yeniden inşa etme için kullanılmaktadır. Dalgacık filtrelerinde ayrık (discrete) ve sürekli (continuous) dalgacık dönüşümlerine ilave olarak dalgacık çoklu çözünürlük (multiresolution) analizi (WMRA) ve dalgacık paket transformasyonu (WPT) olarak da kullanılmaktadır. Zaman alanında $x(t)$ sinyalinin sürekli dalgacık dönüşümü (CWT) şöyle tanımlanmaktadır:

$\operatorname{CWT}(a, \tau)=\frac{1}{\sqrt{a}} \int_{-\infty}^{\infty} x(t) \psi\left(\frac{t-\tau}{a}\right) d t$

Burada $a$ ve $\tau$ değerleri sırasıyla $\psi(t)$ wavelet fonksiyonunun ölçek ve yerdeğiştirme parametreleridir. Zaman alanındaki sinyal dalgacık dönüşümünün ölçeklenmiş ve yer değiştirmiş olan versiyonları ' $a$ ' ölçeğinde ve ' $\tau$ ' ötelemesine göre çoğaltılmaktadır. Ayrık dalgacık dönüşümü (DWT) ayrık bir zaman diliminde verilen $x(n)$ için şöyle tanımlanmaktadır:

$C_{j, k}=2^{(-j / 2)} \sum_{n} x(n) \psi\left(2^{-j} n-k\right)$ 
Bu denklemde $\psi(n)$ dalgacık fonksiyonunu, $2(-j / 2)$ ve $\psi(2-j n-k)$ ise $\psi(n)$ fonksiyonunun ' $j$ ' kadar ölçeklenmiş ve ' $k$ ' kadar ötelenmiş versiyonlarını göstermektedir. Dalgacık fonksiyonu olarak kullanılan ana dalgacıklardan bazıları (a) Daubechies, (b) Mexican hat, (c) Gaussian ve (d) Morlet olarak tanımlanmaktadır.
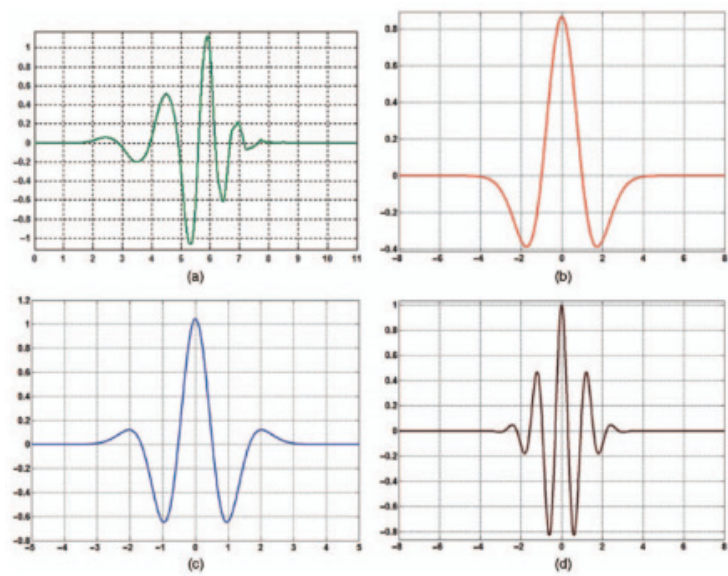

Şekil 2 - (a) Daubechies, (b) Mexican hat, (c) Gaussian ve (d) Morlet Ana Dalgaclk Fonksiyonlarının Gösterimi

Dalgacık çoklu çözünürlük analizi (WMRA), ayrık dalgacık dönüşümünü filtrelerle uygulamak için kullanılan bir tekniktir. Çeşitli çözünürlük ölçeklerinde sinyallerin ayrışmasını sağlamaktadır. İlk olarak Mallat tarafından iki boyutlu görüntü analizleri yapabilmek ve bu işlemleri hızlandırabilmek amacıyla çalışılmıştır. Dalgacık paket dönüşümü (WPT) dalgacık çoklu çözünürlük analizine benzer şekilde sinyali ardışık olarak düşük ve yüksek frekans bileşenlerine tekrarlı olarak ayrıştıran bir tekniktir. Ancak WMRA'dan farklı olarak belirli bir seviyede sadece yaklaşım sinyallerini değil detay sinyallerini de ayrıştırmaya devam etmektedir.
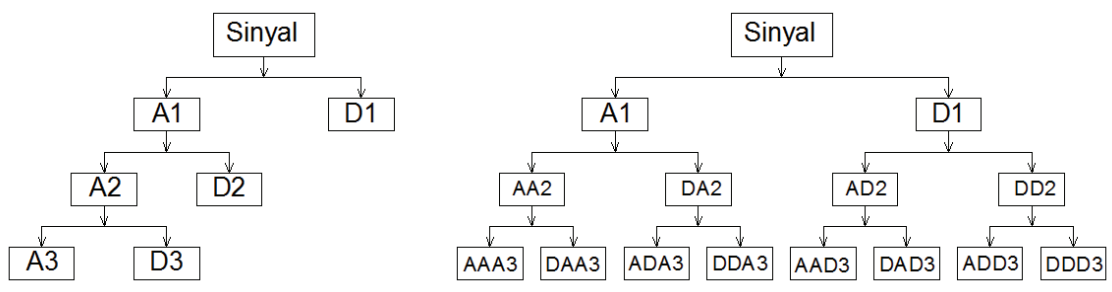

Şekil 3 - WMRA ve WPT Tekniklerinin Karşılaştırılması

Dalgacık paketi ölçekleme fonksiyonlarıyla dalgacık fonksiyonlarının ayrışım ve dönüşümlerin ikili dallarını oluşturan bir ailedir. Böylece dalgacık paketleri sinyal özelliklerinin ortonormalitesi ve bunlara karşılık gelen dalgacık fonksiyonlarından elde 
edilen zaman-frekans konumlarını barındırmaktadır. Bir dalgacık paketi $\Psi_{j, k}^{i}(t)$ ile ifade edilen ve üç indisten oluşan bir fonksiyon ile ifade edilebilir. Burada $i, j$ ve $k$ indisleri sırasıyla modülasyon, ölçek ve çeviri parametreleridir. Denklem şu şekilde ifade edilebilir;

$\Psi_{j, k}^{i}(t)=2^{j / 2} \Psi^{i}\left(2^{j} t-k\right), \quad i=1,2,3 \ldots$

Bu denklemde $i=0$ için $\Psi^{0}(t)=\phi(t)$ ve $i=1$ için $\Psi^{1}(t)=\Psi(t)$ değerini almaktadır. Bu denklemde $\phi(t)$ ölçekleme fonksiyonu ve $\Psi(t)$ ana dalgacık fonksiyonunu ifade etmektedir. $i>1$ olması durumunda $\Psi^{\mathrm{i}}$ ana dalgacık fonksiyonu aşağıdaki gibi ifade edilebilir;

$\Psi^{2 i}=\sqrt{2} \sum_{k} h(k) \Psi^{i}(2 t-k)$

$\Psi^{2 i+1}=\sqrt{2} \sum_{k} g(k) \Psi^{i}(2 t-k)$

Burada $h(k)$ ve $g(k)$ ana dalgacık fonksiyonu ile ilişkili dördün ayna filtreleri ve ölçekleme fonksiyonlarıdır. Dalgacık dönüşümünün modülünün karesi zaman ölçekli düzlem üzerinde enerji yoğunluğu dağılımı olarak yorumlanabilir. Bir sinyalin enerjisi ağırlıklı olarak zaman ölçekli düzlemde dalgacık dönüşümünün tepelerinde yoğunlaşmaktadır. Hasar tespiti için temel bir özellik olarak doğal frekanslara nazaran mod şekilleri ve bunların türevlerinin daha faydalı olduğu açık olarak görülmektedir (Farrar ve James [23]). İlk olarak mod şekilleri yerel bilgileri içermektedir. $\mathrm{Bu}$ da onları yerel hasarları ve çoklu hasar konumunu tespit etmek için daha hassas hale getirmektedir. İkincisi mod şekilleri sıcaklık gibi çevresel etkilere karşı doğal frekanslara nazaran daha az duyarlıdır.

\section{ANALİZ YÖNTEMLERININ ANALITIK YAPILARA UYGULANMASI}

Türk Standartları (TS) 500 ve Deprem Bölgelerinde Yapılacak Binalar Hakkında Yönetmelik (DBYBHY) 2007'ye uygun olarak modellenen dört katlı analitik çerçevede kolonlar 30x60, kirişler 25x50 olarak seçilmiştir. X yönlü açıklıklar 4 m, kat yüksekliği 3 m'dir. Toplamda 24 kolon ve bunları birbirine bağlayan kirişlerle çerçeve oluşturulacak sinüs girdi kuvveti ile hasar verilerek modal parametreler tespit edilecektir.

İkinci örnekte ise benzer yapı üç boyutlu çerçeve olarak da modellenerek deprem kuvvetleri uygulanarak dalgacık dönüşümü ile hasar anomalisinin yapısal performansa bağlı olarak nasıl değiştiği tespit edilmeye çalışılacaktır.

Üçüncü örnekte daha komplike bir yapı Perform 3D programıyla analiz edilerek sürekli ve dalgacık paket dönüşümü üzerinden relatif ivme, hız ve deplasman parametreleri ile mutlak ivme kayıtlarına bakılarak çalışılmıştır. Ayrıca hız parametrelerinden elde edilen enerji değerlerinin zaman-frekans çözünürlükleri incelenmiştir.

\section{1. İki Boyutlu Çerçeve Yapının Modal Parametrelerinin Sonlu Elemanlar Metodu ile Belirlenmesi}

Yapı eşdeğer deprem yükü, spektral yükleme ve zaman tanım alanında deprem kaydı ile analiz edilmiştir. Yapı periyodu, yumuşak kat, zayıf kat, burulma düzensizliği durumu, göreli 
kat ötelemesi ve 2. Mertebe gösterge değeri kontrolleri DBYBHY2007'ye göre uygun aralıklarda çıkmıştır. Yapının modal parametreleri sonlu elemanlar metodu ile belirlenmiştir.

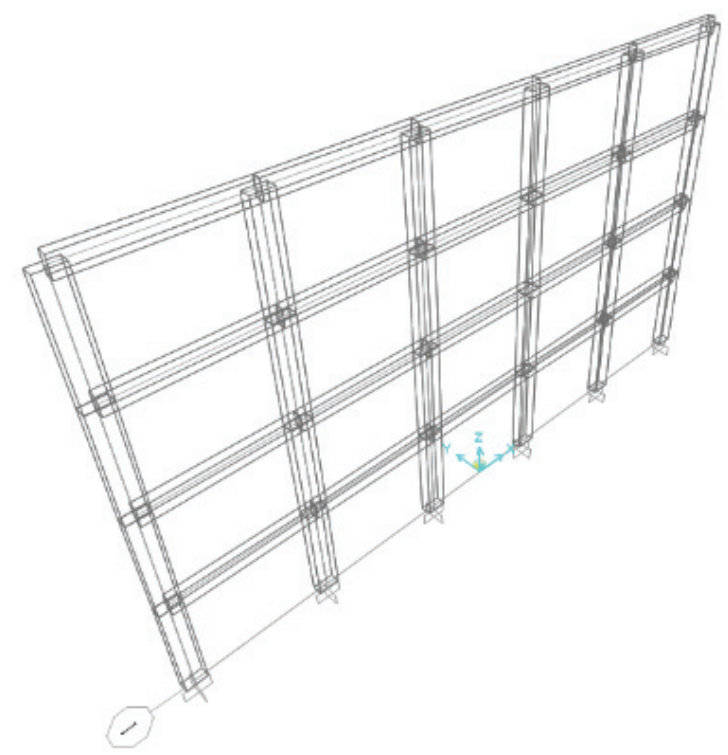

Şekil 4 - Yapı 3B Görünümü

Tablo 1 - Hasarsı Yapı Periyodunun Sonlu Elemanlar Metoduyla Tespit Edilmesi

TABLE: Modal Participating Mass Ratios

\begin{tabular}{|c|c|c|c|c|c|c|}
\hline OutputCase & StepType & StepNum & Period & UX & UY & SumUX \\
\hline Text & Text & Unitless & Sec & Unitless & Unitless & Unitless \\
\hline MODAL & Mode & 1 & 0,195 & 0,829 & 0 & 0,82951 \\
MODAL & Mode & 2 & 0,0602 & 0,113 & 0 & 0,94325 \\
MODAL & Mode & 3 & 0,033 & 0,043 & 0 & 0,98658 \\
MODAL & Mode & 4 & 0,023 & 0,013 & 0 & 0,99999 \\
\hline
\end{tabular}

$\mathrm{X}$ yönü için periyot modelimizde 0,195 sn çıkmıştır. Yapı periyot değerleri DBYBHY2007'de tanımlanan üst sınırı aşmadığından modal parametreler uygun aralıkta kalmaktadır.

\subsection{Yapı Deprem Performansının Deprem Kayıt Hareketi İle Doğrusal Olmayan Metotla Belirlenmesi}

Yapının modal parametreleri kuvvetli shaker kuvveti ile doğrusal olmayan analiz ile SAP2000 programıyla analiz edildiğinde aşağıdaki sonuçlara ulaşılmaktadır. Burada sin fonksiyonu x yönlü ivme olarak çerçeveye etkitilmiştir. 


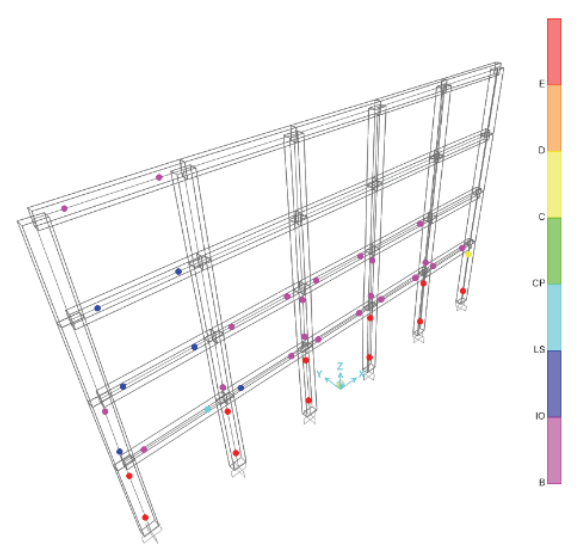

Şekil 5 - Kuvvetli Deprem Zaman Tanım Alanında Analiz Sonucu Mafsallaşma Grafiği

Yapıdaki kolonların mafsallaşması incelendiğinde 1. ve 2. katta bir takım elemanların göçme öncesi performans seviyesini aştığ1 gözlemlenmiştir. Buradaki referans şekil değiştirme parametreleri DBYBHY2007 değerleri baz alınarak değiştirilmiştir.

\subsection{Hasarlı ve Hasarsız Parametreler Üzerinden Dalgacık Analizi Metodu ile Hasar Tanılama Çalışması}

Yapısal hasar oluşan kolonun alt ve üstünde bulunan kolonlarla birlikte noktasal ivme ölçümü yapılarak, bu noktaların ve hasarlı durumlarının parametreleri Db4 ve Morlet dalgacık filtreleri ile incelenerek iki durum arasındaki farklılıklar tespit edilmeye çalışılmıştır. Bunun için gerekli kodlar MATLAB programıyla yazılmıştır.
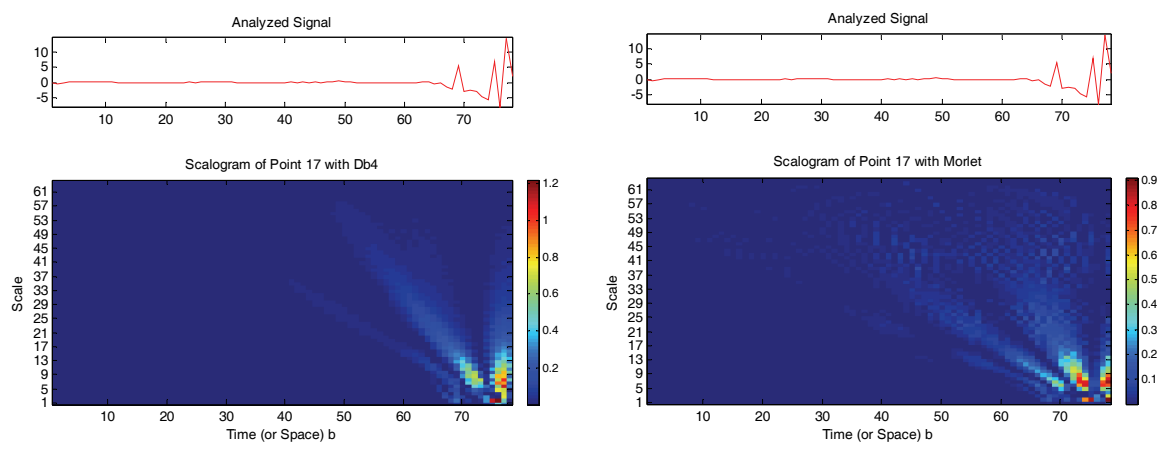

Şekil 6 - 17 Numaralı Hasarlı Noktanın Db4 ve Morlet ile Analizi

17 numaralı elemanda maksimum ivme değerlerinin $10 \mathrm{~m} / \mathrm{sn}^{2}$ seviyelerine kadar yükseldiği ve dalgacık filtrelerinde grafiğin sadece sağ alt kısmında enerji yığılmalarının olduğu gözlemlenmiştir. 

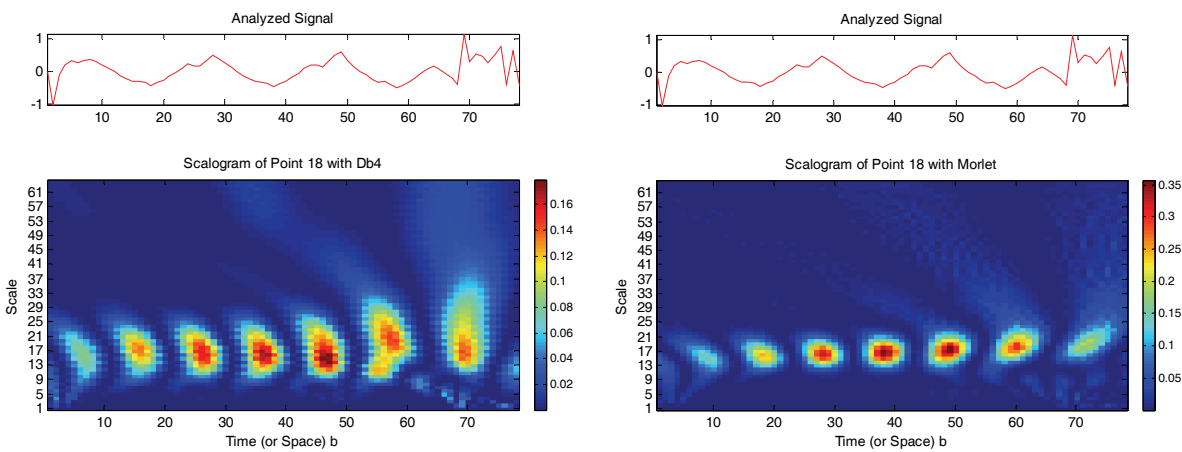

Şekil 7 - 18 Numaralı Hasarll Noktanın Db4, Morlet, Mexh ve Sym2 ile Analizi
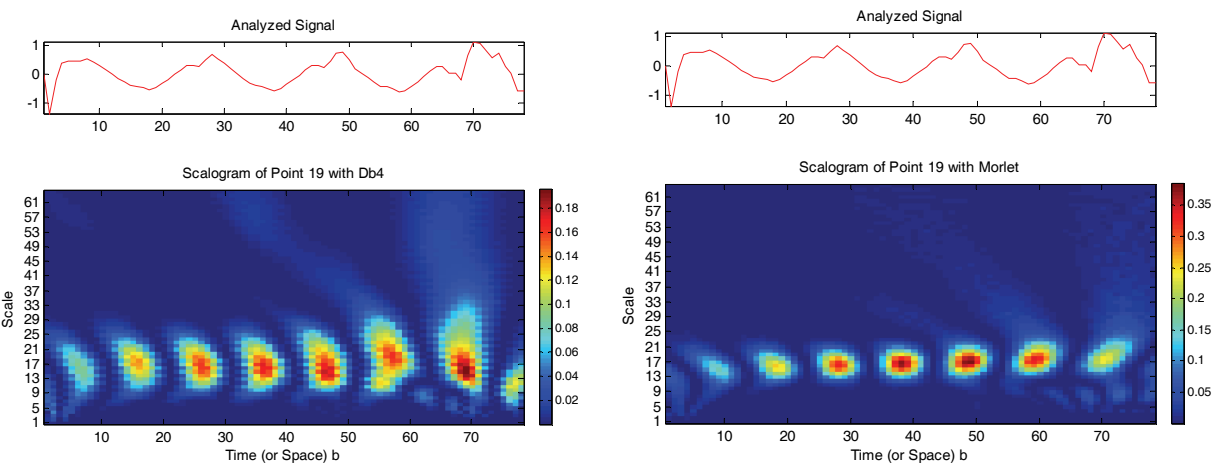

Şekil 8 - 19 Numaralı Hasarlı Noktanin Db4 ve Morlet ile Analizi
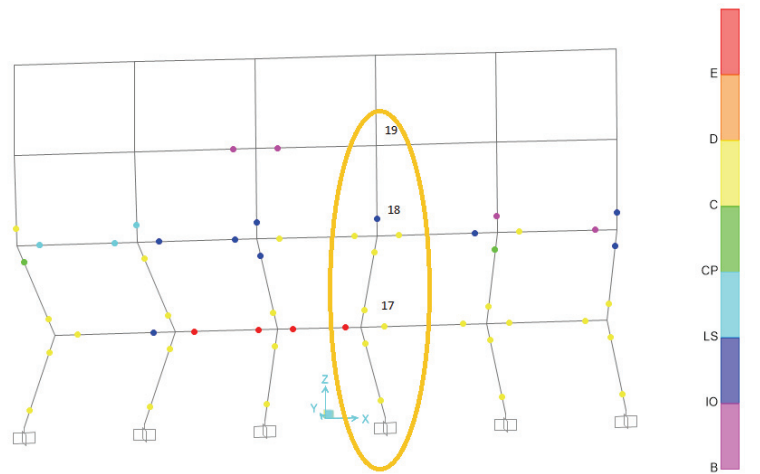

Şekil 9 - Kuvvetli Shaker Kuvveti Sonrası Yapının Hasar Seviyeleri 

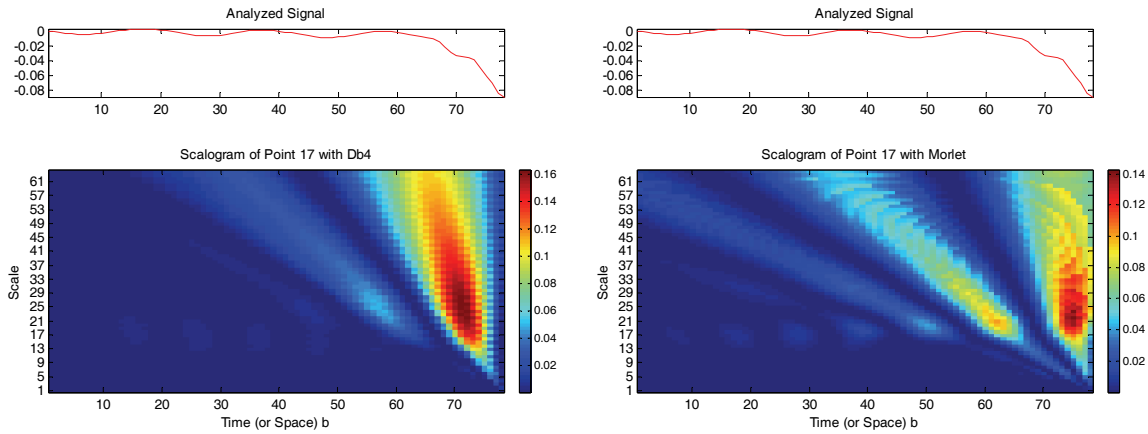

Şekil 10 - 17 Numaralı Hasarlı Nokta Deplasmanlarının Db4 ve Morlet ile Analizi

17 numaralı elemanda maksimum deplasman değerlerinin $8 \mathrm{~cm}$ seviyelerine kadar yükseldiğ i ve dalgacık filtrelerinde grafiğin sadece sağ kısmında enerji yığılmalarının olduğu gözlemlenmiştir. Grafiklerde frekans mertebesinin ölçek ile ters orantılı olarak zamanla düştüğü gözlemlenmiştir.
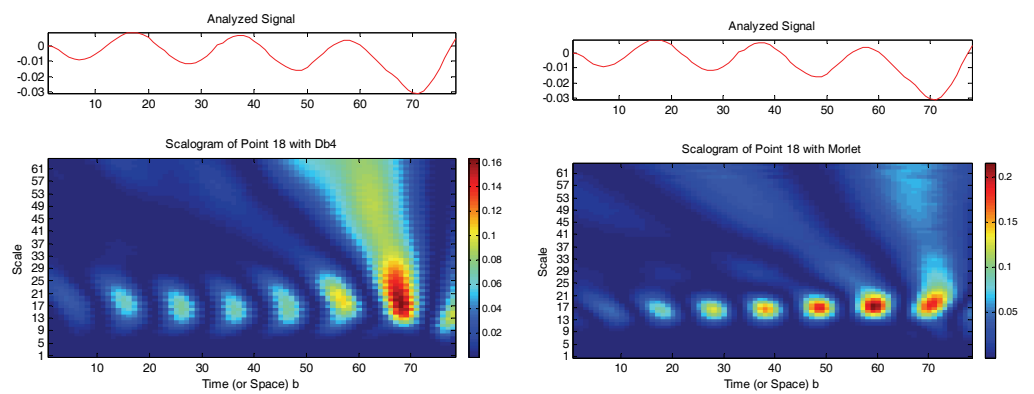

Şekil 11 - 18 Numaralı Hasarlı Nokta Deplasmanlarının Db4 ve Morlet ile Analizi
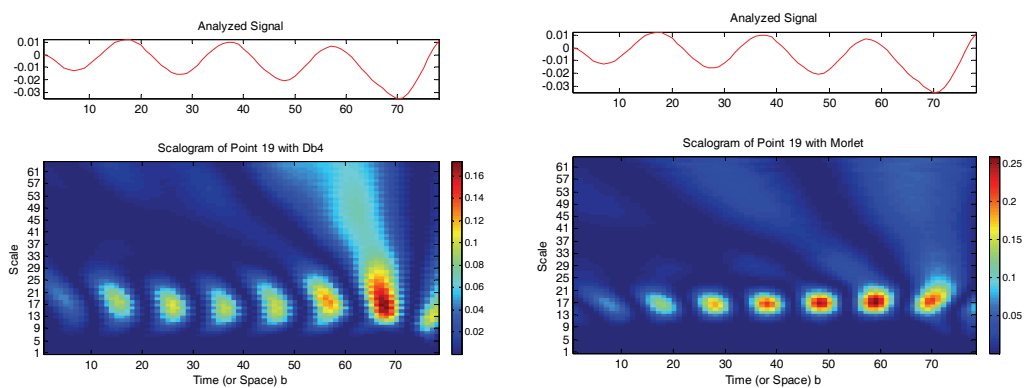

Şekil 12 - 19 Numaralı Hasarlı Nokta Deplasmanlarının Db4 ve Morlet ile Analizi

Hasarlı ve hasarsız elemanların ivme parametreleri ile sürekli dalgacık dönüşümü yapıldığında hasar oluşumu ile ilgili olarak net bir görüntü elde edilebilmektedir. Yerel üst 
çizgilerinde son aşamada kırıklara rastlanmaktadır. Bu çapraz kırılmalar hasara işaret eden bir parametre olarak değerlendirilebilir. Aynı kuvvet etkisi altında hasarlı eleman ivme değerlerinin hasarsıza göre on kat fazla olması da elemanın hasar almasıyla ilişkilendirilebilir.

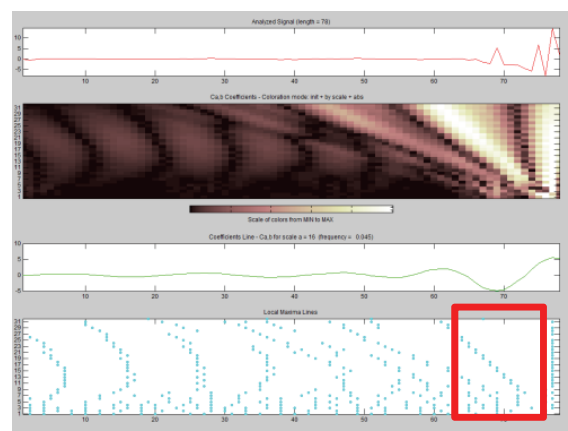

Şekil 13 - 17 Nurmaralı Hasarlı Noktanın Ivme Değerlerinin Db4 Ile Analizi

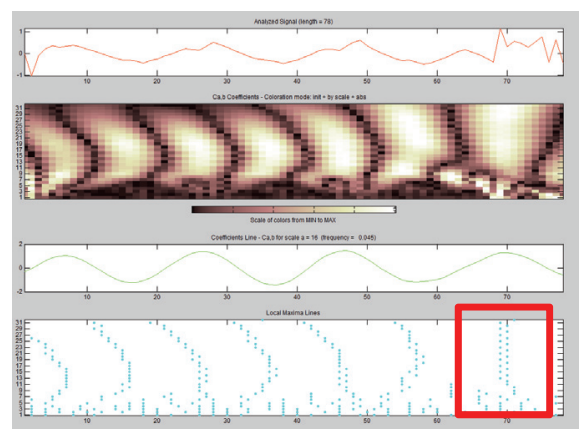

Şekil 14 - 18 Nurmaralı Hasarlı Noktanın Ivme Değerlerinin Db4 ile Analizi

Hasarsız noktayı ele aldı̆̆ımızda yerel üst çizgisinin tekrar hasarlı elemandan farklı olarak süreklilik gösterdiğini belirtebiliriz. Dalgacık paket dönüşümü ile hasarlı ve hasarsız elemanlara bakıldığında hasar anında belirgin bir şekilde tespit yapılabilmektedir. Hasarlı ve hasarsız elemanların enerji parametrelerine bakıldığında ise aynı kuvvetin etkidiği iki benzer kirişten hasarlı olanın enerji değerleri hasarsız olana göre 4 kat daha fazla çıkmaktadır. $\mathrm{Bu}$ durum dalgacık paket dönüşümünde de belirgin bir şekilde görülmekte ve hasar belirtileri koyu kırmızı renklerle grafiğin sağ kısmında yoğunlaşmaktadır. Hasarsız elemanda ise bu değerler zamana yayılı bir şekilde görülmektedir.

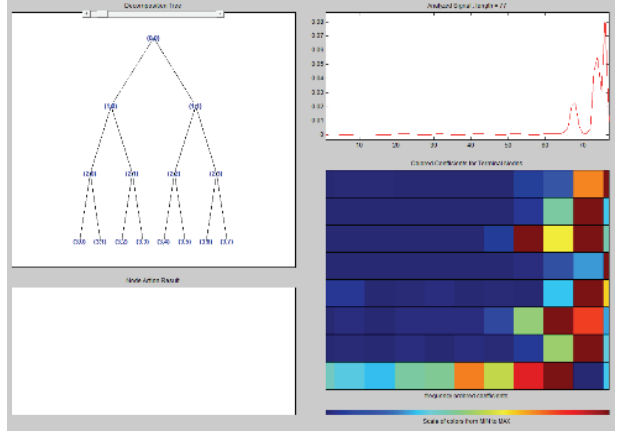

Şekil 15 - 17 Nurmaralı Hasarlı Noktanın Ívme Değerlerinin Db4 Ille Dalgacık Paket Dönüşümü

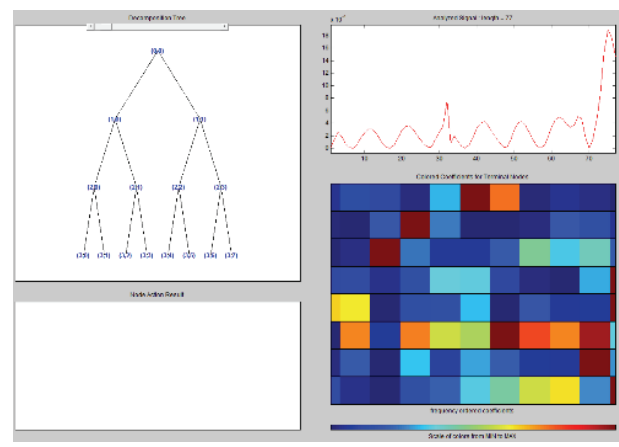

Şekil 16 - 18 Nurmaralı Hasarlı Noktanin İvme Değerlerinin Db4 Ile Dalgacık Paket Dönüşümü

Sonuç olarak hasar tespitinde ayrık, sürekli ve dalgacık paket dönüşümünün yanı sıra yerel üst çizgilerinin de belirleyici faktörler olduğu anlaşılmaktadır. 


\section{4. Üç Boyutlu Çerçeve Yapının Modal Parametrelerinin Sonlu Elemanlar Metodu ile Belirlenmesi}

Yapı eşdeğer deprem yükü, spektral yükleme ve zaman tanım alanında deprem kaydı ile analiz edilmiştir. Yapı periyodu, yumuşak kat, zayıf kat, burulma düzensizliği durumu, göreli kat ötelemesi ve 2. Mertebe gösterge değeri kontrolleri DBYBHY2007'ye göre uygun aralıklarda çıkmıştır. Yapının modal parametreleri sonlu elemanlar metodu ile belirlenmiştir.

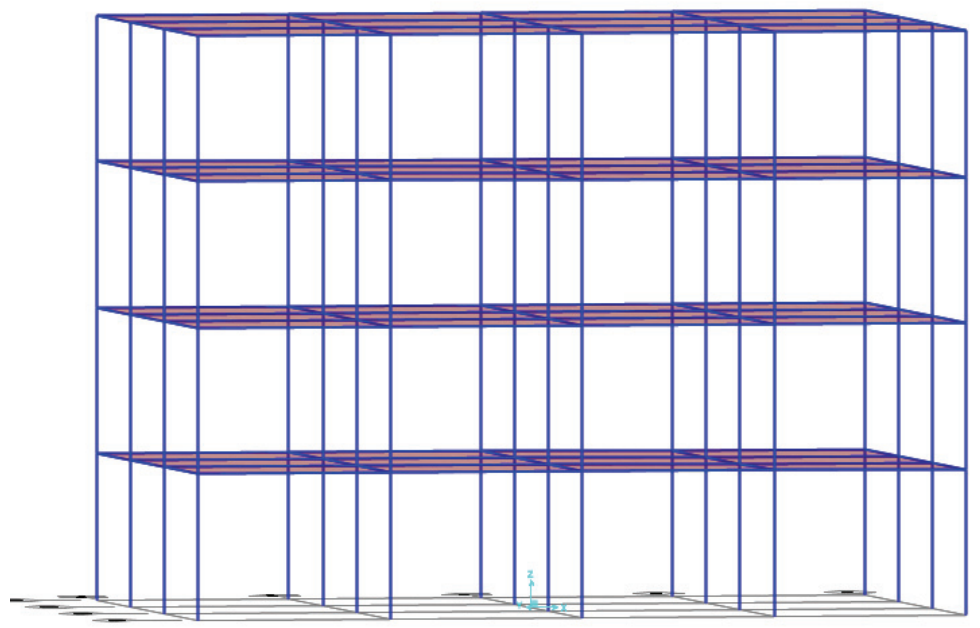

Şekil 17 - İki Boyutlu Çerçeve Yapı 3B Görünümü

Tablo 2 - Hasarsı (Modal) ve Hasarlı (Modal-NL) Yapı Periyodunun Sonlu Elemanlar Metoduyla Tespit Edilmesi

\begin{tabular}{|c|c|c|c|c|c|c|}
\hline \multicolumn{7}{|c|}{ TABLE: Modal Periods And Frequencies } \\
\hline OutputCase & StepType & StepNum & Period & Frequency & UX & UY \\
\hline Text & Text & Unitless & Sec & Cyc/sec & Unitless & Unitless \\
\hline MODAL & Mode & 1 & 0,408 & 2,450 & 0 & 0,94059 \\
\hline MODAL & Mode & 2 & 0,283 & 3,530 & 0 & 0 \\
\hline MODAL & Mode & 3 & 0,260 & 3,845 & 0,93272 & 0 \\
\hline MODAL & Mode & 4 & 0,095 & 10,537 & 0 & 0,05932 \\
\hline MODAL-NL & Mode & 1 & 0,402 & 2,488 & 0 & 0,93739 \\
\hline MODAL-NL & Mode & 2 & 0,301 & 3,323 & 0 & 0,00021 \\
\hline MODAL-NL & Mode & 3 & 0,274 & 3,647 & 0,94233 & 0 \\
\hline MODAL-NL & Mode & 4 & 0,094 & 10,651 & 0 & 0,06229 \\
\hline
\end{tabular}


$X$ yönü için hakim olan 3. modun periyodu hasarsız modelimizde 0,260 sn iken hasarlı modelde 0,274 sn'ye yükselmiştir. Y yönü için hakim olan 1 . modun periyodu ise hasarsız modelimizde 0,408 sn iken hasarlı modelimizde 0,402 sn'ye inmiştir.

\subsection{Yapı Deprem Performansının Deprem Kayıt Hareketi İle Doğrusal Olmayan Metotla Belirlenmesi}

Yapının modal parametreleri kuvvetli deprem kuvveti ile doğrusal olmayan analiz ile SAP2000 programıyla analiz edildiğinde aşağıdaki sonuçlara ulaşılmaktadır. Kuvvet kaydı olarak olarak 17 Ağustos 1999 Kocaeli depremi kullanılmıştır.

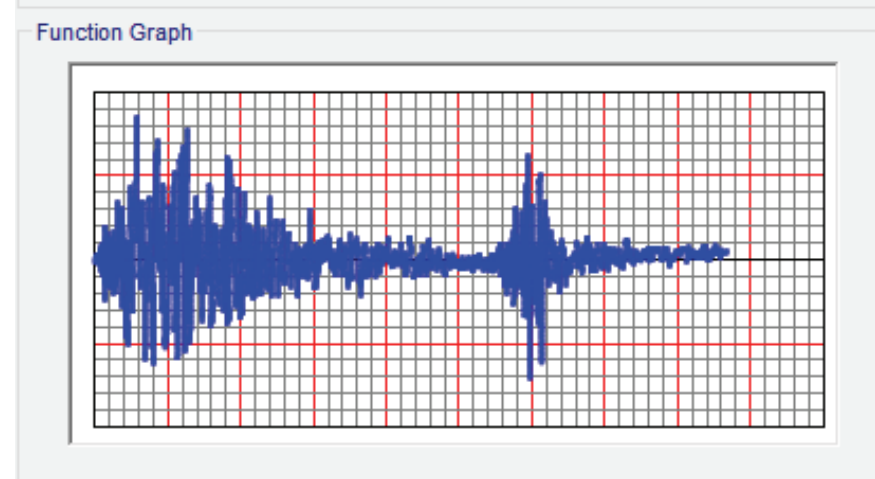

Şekil 18 - 17 Ağustos 1999 Kocaeli Merkez Meteoroloji İstasyon Müdürlüğ̈̈ Deprem Kaydı
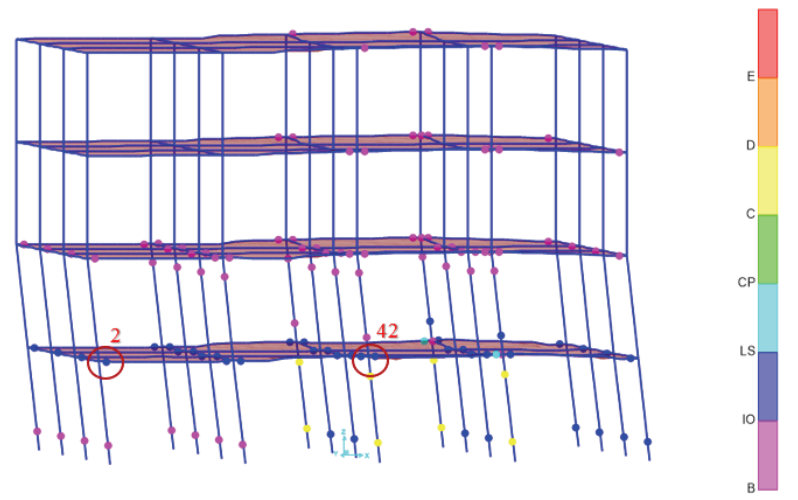

Şekil 19 - Kuvvetli Deprem Zaman Tanım Alanında Analiz Sonucu Mafsallaşma Grafiği

Yapıdaki kolonların mafsallaşması incelendiğinde 1. Katta ileri hasar seviyesine ulaşan elemanlar ve 2. katta bir takım elemanların göçme öncesi performans seviyesini aştığ1 gözlemlenmiştir. Buradaki referans şekil değiştirme parametreleri DBYBHY2007 değerleri baz alınarak değiştirilmiştir. 


\subsection{Hasarlı ve Hasarsız Parametreler Üzerinden Dalgacık Analizi Metodu ile Hasar Tanılama Çalışması}

Yapısal hasar oluşan kolonun alt ve üstünde bulunan kolonlarla birlikte noktasal ivme ölçümü yapılarak, bu noktaların hasarsız (zayıf shaker kuvveti) ve hasarlı (kuvvetli shaker kuvveti) durumlarının parametreleri Db4, Morlet, Mexican Hat ve Symlet dalgacık filtreleri ile incelenerek iki durum arasındaki farklılıklar tespit edilmeye çalışılmıştır. Bunun için gerekli kodlar MATLAB programıyla yazılmıştır. Yapılan analizler sonucunda Db4 ve Mexh dalgacık modellerinin analiz yapımız için uygun ve yeterli oldukları görülmüştür. İlgili kodlar çalışmamızın Ek-1 kısmında verilmiştir. Burada 2 ve 42 numaralı elemanların hasarlı ve hasarsız ivme ve deplasman kayıtlarından yola çıkılarak hasar alan 42 nolu elamanın dalgacık transformasyonundaki belirgin farklarına bakılacaktır.

Öncelikle hasarsız durumu ele aldığımızda aşağıdaki değerlere ulaşılmaktadır.
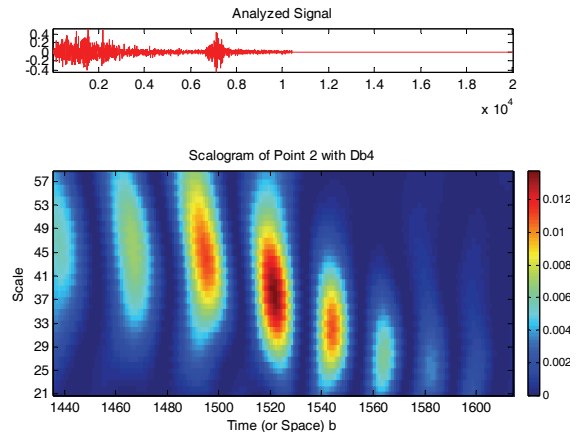

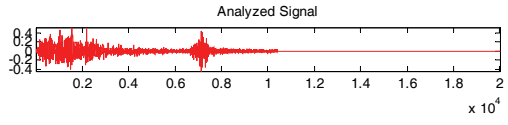

Scalogram of Point 2 with Mexh

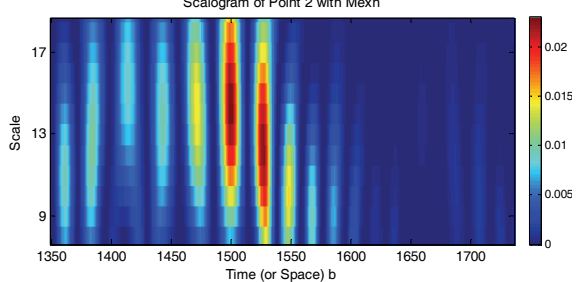

Şekil 20 - 2 Numaralı Hasarsız Noktanın Db4 ve Mexh ile Analizi
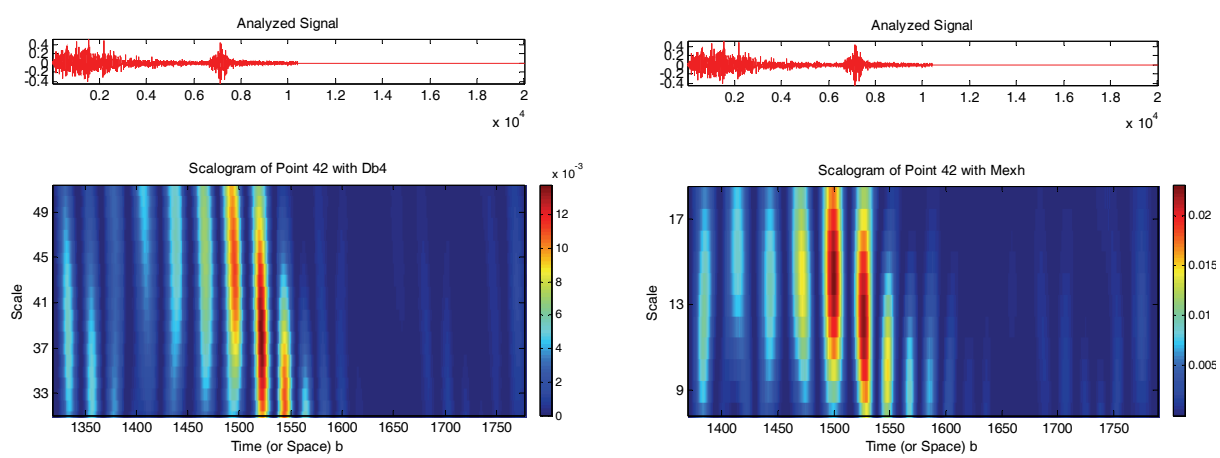

Şekil 21 - 42 Numaralı Hasarsız Noktanın Db4 ve Mexh ile Analizi

Zaman çizelgesindeki değerler 0,005 mertebesinde ilerlediğinden 1525. adım yaklaşık olarak 7,62 saniyeye denk gelmektedir. Bu zaman dilimide ölçek şiddeti db4 dalgacık ailesinde 40 değerini, Mexh dalgacık modelinde ise 13 değerini vermektedir.

Hasarlı durumu ele aldığımızda aşağıdaki değerlere ulaşılmaktadır. 

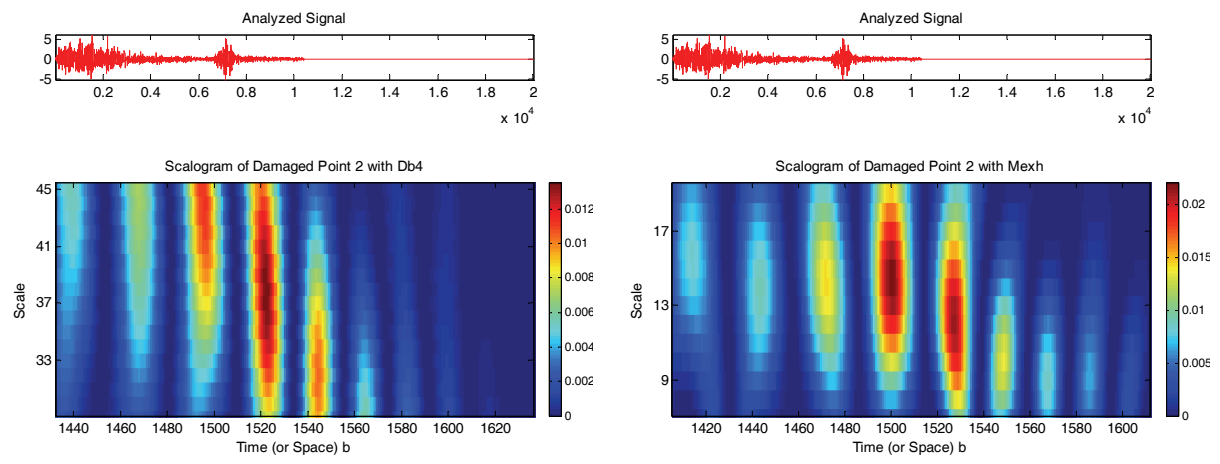

Şekil 22 - 2 Numarlı Hasarlı Noktanın Db4 ve Mexh ile Analizi
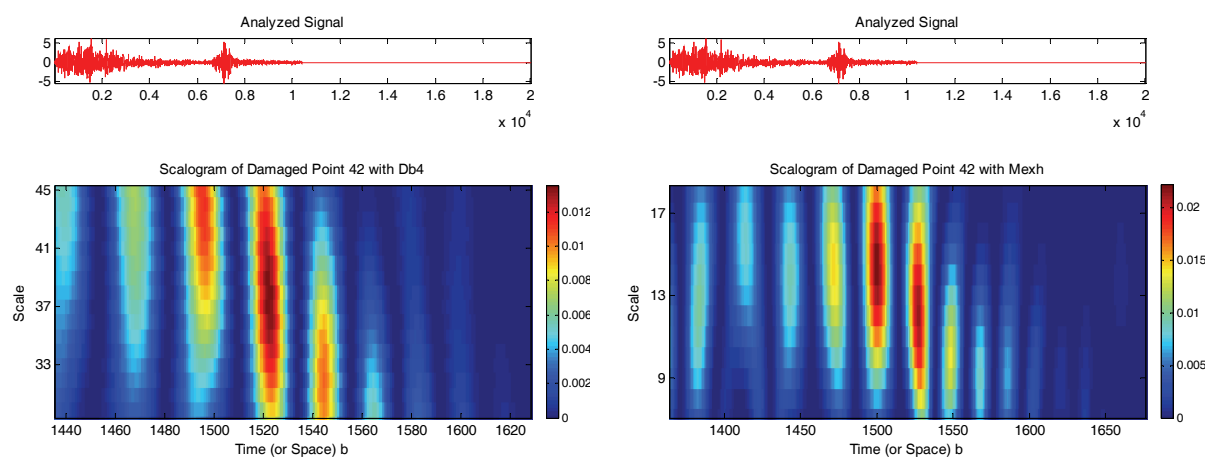

Şekil 23 - 42 Numarlı Hasarlı Noktanin Db4 ve Mexh ile Analizi

Zaman çizelgesindeki değerler 0,005 mertebesinde ilerlediğinden 1525 . adım yaklaşı olarak 7,62 saniyeye denk gelmektedir. Bu zaman diliminde ölçek şiddeti Db4 dalgacık ailesinde 37 mertebesine inmektedir. Yani yapı elemanındaki frekans ölçek ile ters orantılı olarak yükselmiştir. Aynı analizler 2 ve 42 numaralı elemanların deplasman değerleri üzerinden tekrarlanacaktır. $\mathrm{Bu}$ analizde ise en uygun dalgacık türü Morlet ve Mexh olmaktadır.
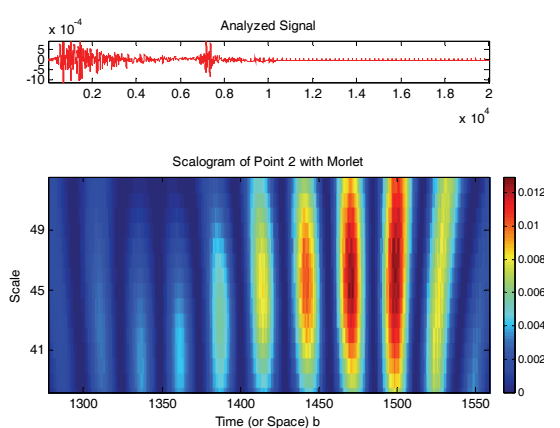
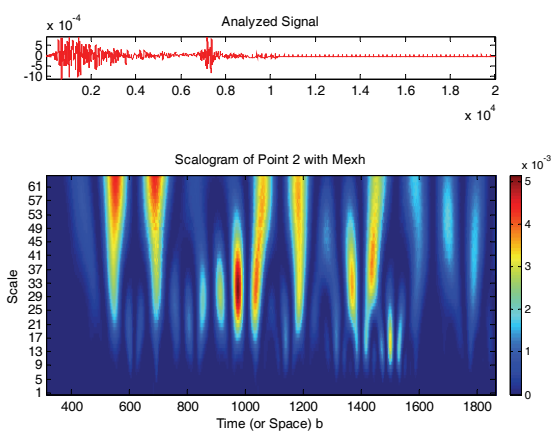

Şekil 24 - 2 Numaralı Hasarsız Noktanın Morlet ve Mexh ile Analizi 

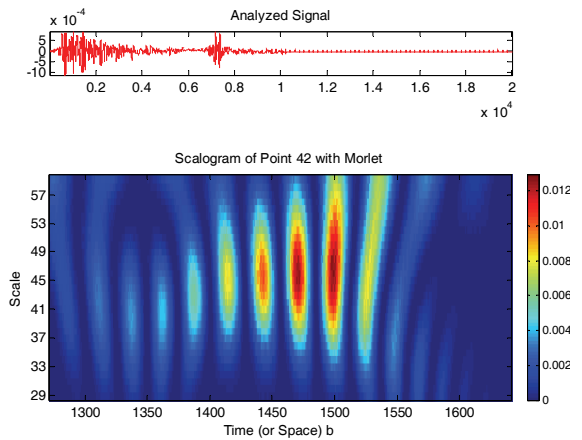
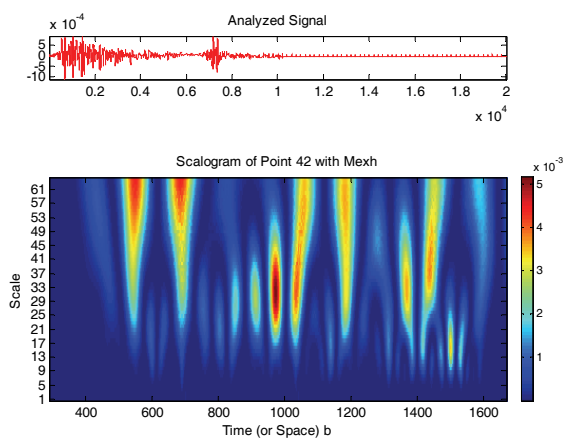

Şekil 25 - 42 Numaralı Hasarsız Noktanın Morlet ve Mexh ile Analizi

Zaman çizelgesindeki değerler 0,005 mertebesinde ilerlediğinden 1500 . adım yaklaşık olarak 7,50 saniyeye denk gelmektedir. Bu zaman dilimide ölçek şiddeti Morlet dalgacık ailesinde 47 değerini, Mexh dalgacık modelinde ise 5. saniyede 33 değerini vermektedir. Hasarlı durumu ele aldığımızda aşağıdaki değerlere ulaşılmaktadır.

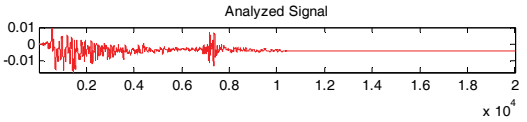

Scalogram of Damaged Point 2 with Morlet

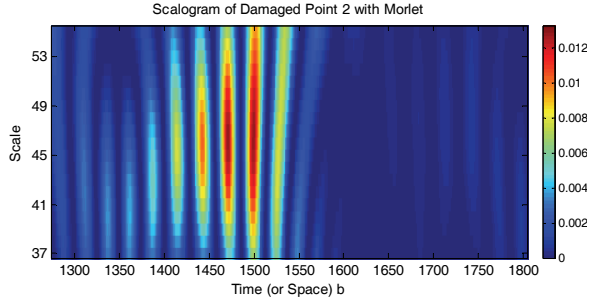

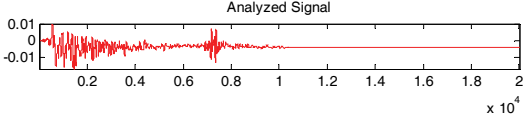

Scalogram of Damaged Point 2 with Mexh

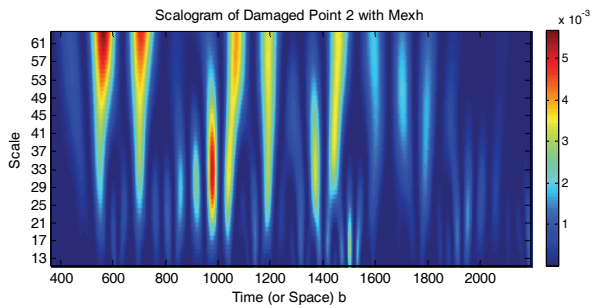

Şekil 26 - 2 Numarlı Hasarlı Noktanın Morlet ve Mexh ile Analizi
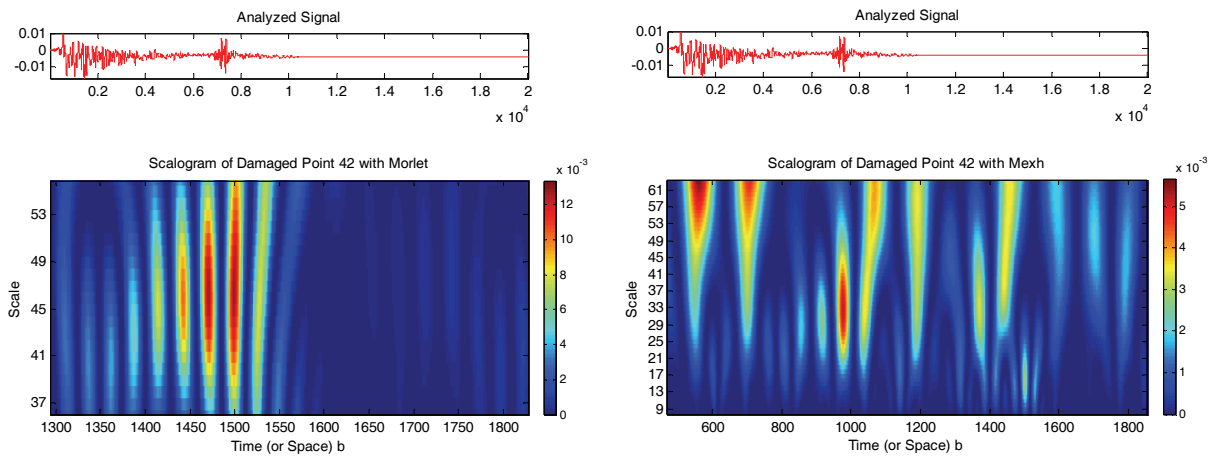

Şekil 27 - 42 Numarlı Hasarlı Noktanın Morlet ve Mexh ile Analizi 
Zaman çizelgesindeki değerler 0,005 mertebesinde ilerlediğinden 1500. adım yaklaşık olarak 7,50 saniyeye denk gelmektedir. Bu zaman dilimide ölçek şiddeti Morlet dalgacık ailesinde 46 değerini, Mexh dalgacık modelinde ise 5. saniyede 32 değerini vermektedir. Burada deplasman kaydından da frekans değerinin düştüğü sonucuna ulaş1labilir. Frekans değerinin düşmesi yapının hasar aldığını göstermektedir.

Ayrıca hasarlı ivme kayıtlarından morlet dalgacık metoduyla incelendiğince hasar alan 42 numaralı elemanın 2 numaralı elemandan farklı olarak yerel üst çizgilerinde süreklilik gözlemlenmiştir. Bu süreksizlik de yapı elemanının hasar alması olarak değerlendirilmiştir.

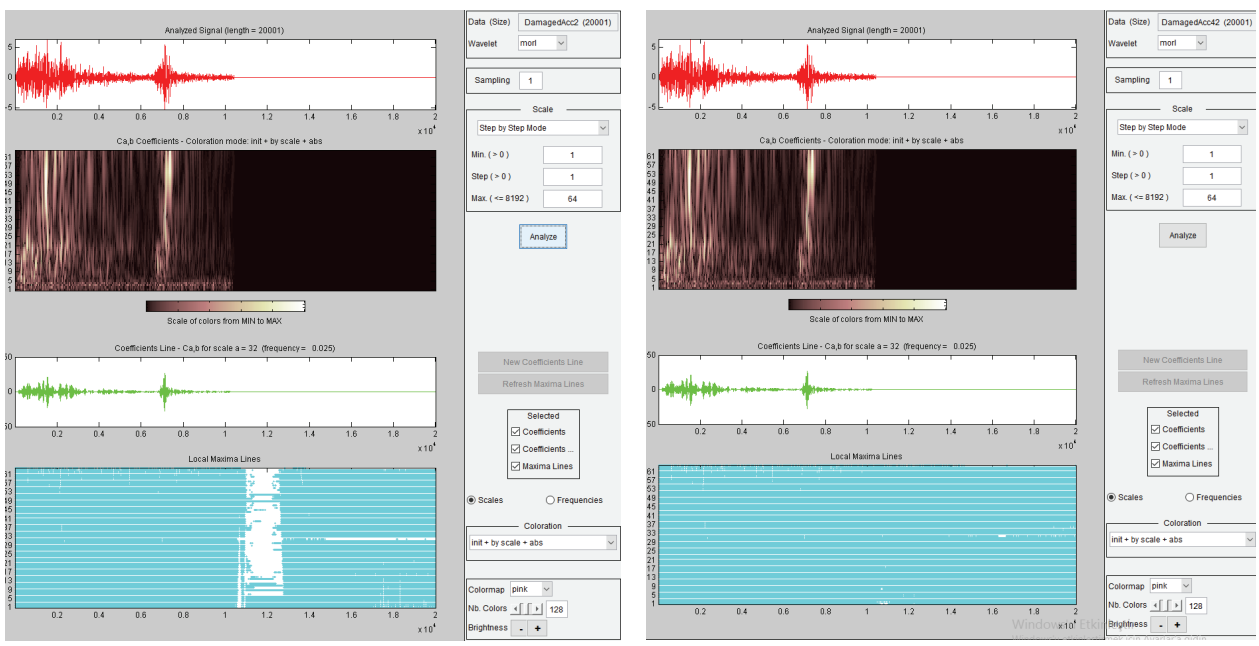

Şekil 28 - 2 ve 42 Numarlı Hasarlı Noktaların Morlet ile Analizi ve Yerel Üst Çizgileri

Hasarlı elemanın deprem öncesi ve sonrasında elde edilen deplasman değerleriyle Db4 dalgacık paket dönüşümü yapıldığında frekans düzenli katsayılarda yığılma gözlemlenmektedir. Bu yoğunluk ve dağılım parametreleri de hasara işaret etmektedir. İki boyutlu analitik modelimizle benzer şekilde hasarlı elemanın dalgacık paket dönüşümü grafiğinde bölgesel yoğunlaşma gözlemlenirken hasarsız elemanda böyle bir yoğunlaşma zamana yayılı olarak görülmektedir.
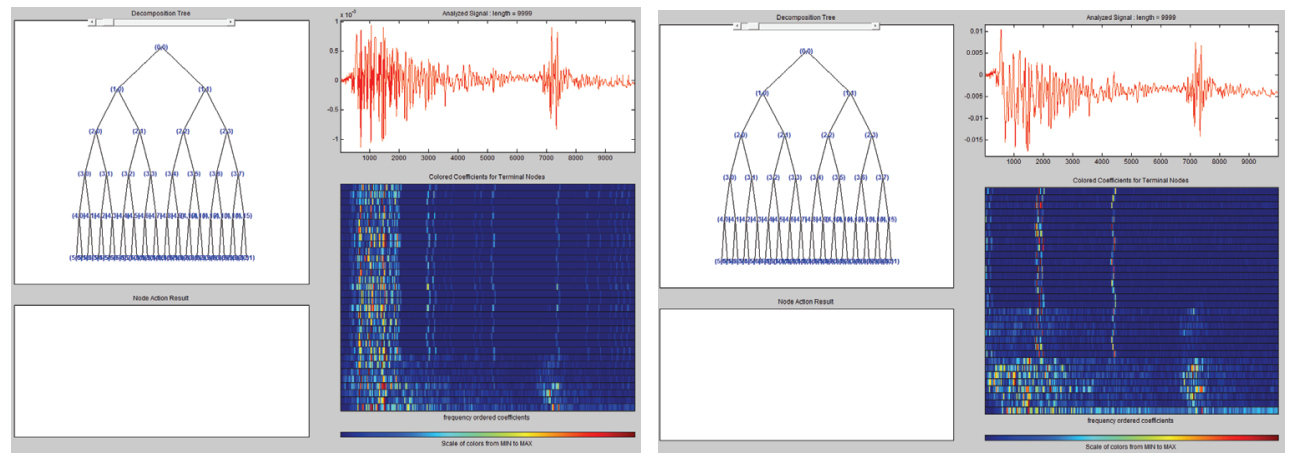

Şekil 29 - 42 Numaralı Noktanın Hasarsız ve Hasarlı Dalgacık Paket Dönüşümü 


\section{7. Üç Boyutlu Analitik Yapı Üzerine Yapılan Çalışmalar}

Bu örnekte 3 katlı L şeklinde planlanmış olan analitik modelde 72 kolon ve bunları birbirine bağlayan kirişler bulunmaktadır. Yapı 1994 Northridge depremiyle analiz edilerek kinetik ve kinematik değerleri elde edilmiştir. Sonrasında bu değerler üzerinden dalgacık dönüşümleri çalışılmıştır.

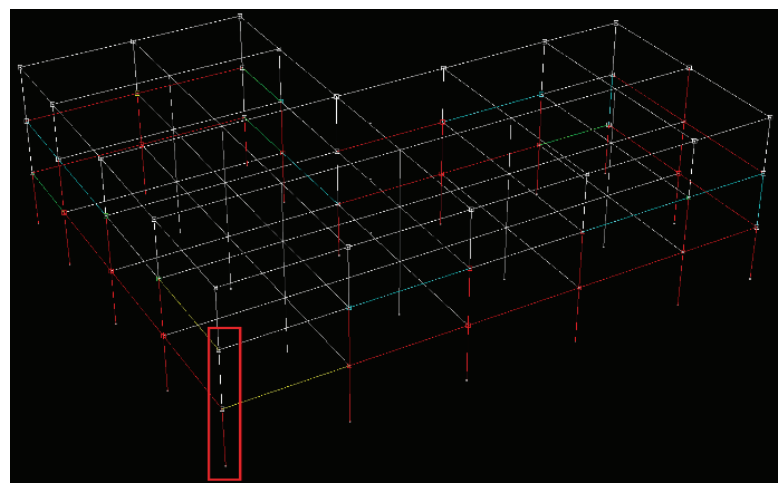

Şekil 30 - Perform 3D Analitik Modeli ve Hasar Alan Elemanlar

Yapının enerji tüketim grafiği incelendiğinde 9. saniyeden sonra ani artışlar gözlenmektedir.

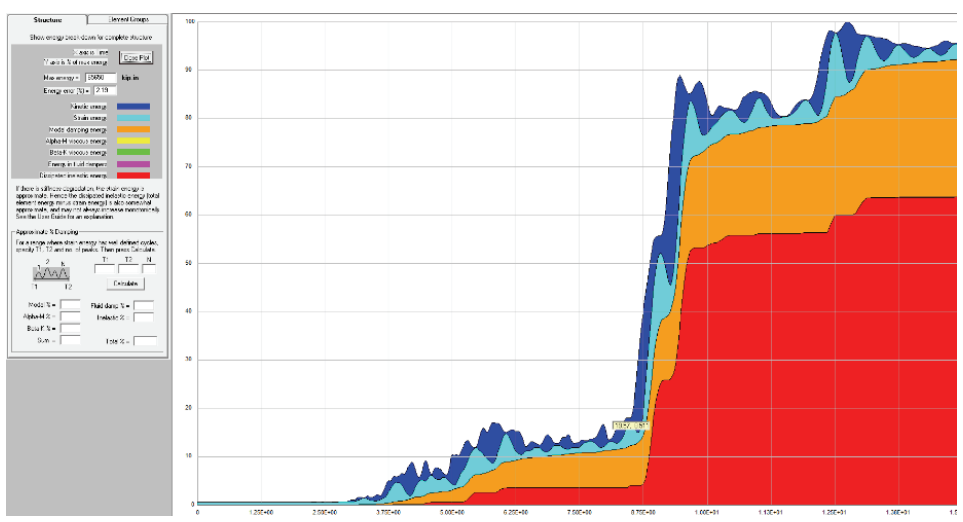

Şekil 31 - Analitik Modelin Enerji Tüketim Parametreleri

Yapının hasar alan elemanının üst noktası (1) ile hasar almayan elemanın üst noktalarının (2) Perform 3D programına göre $\mathrm{H} 1, \mathrm{H} 2$ ve V yönlerindeki relatif ivme, hız, deplasman değerleri ve mutlak ivme değerleri üzerinden sürekli dalgacık dönüşümü ve dalgacık paket dönüşümü çalışmaları yapılmıştır. Ayrıca hız parametresinden enerji alanına geçiş yapılarak bu iki elemanın arasındaki farklar gözlemlenmiştir. Dalgacık paket dönüşümünde sym6, sürekli dalgacıkta ise Morlet kullanılmıştır. 

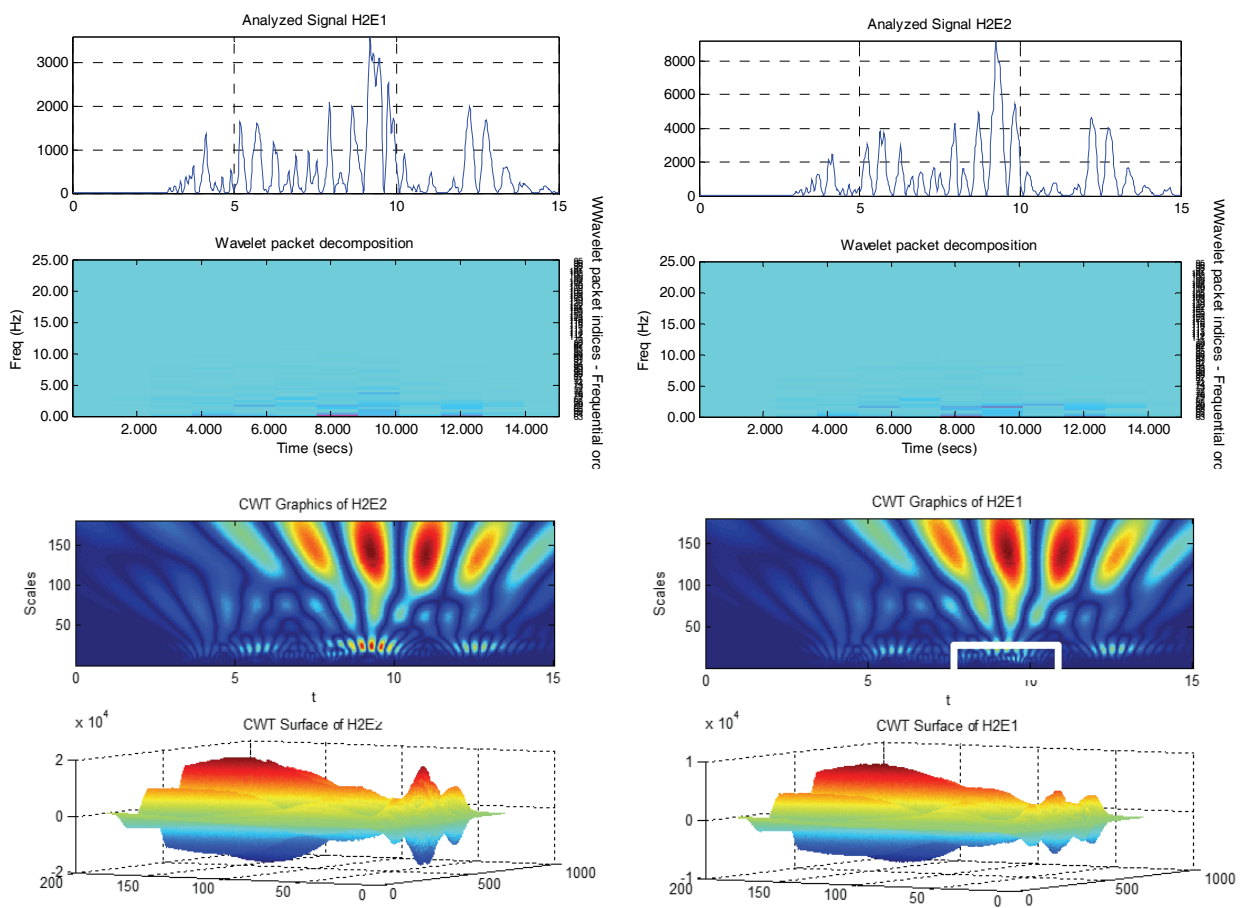

Şekil 32 - Analitik Modelin Enerji Parametresi Üzerinden Dalgacık Dönüşümleri

H2 yönlü enerji grafikleri karşılaştırıldığında 2 numaralı hasarsız elemanda yer alan yüksek frekans mertebesinin hasar alan elemanda azaldığını gözlemlemekteyiz. Enerji değerlerinin 9. Saniyeden sonra değiştiğini ve bunun yapı enerji tüketimiyle aynı zamanda gerçekleştiğini belirtebiliriz. Yani hasar doğru zamanda yakalanmıştır.
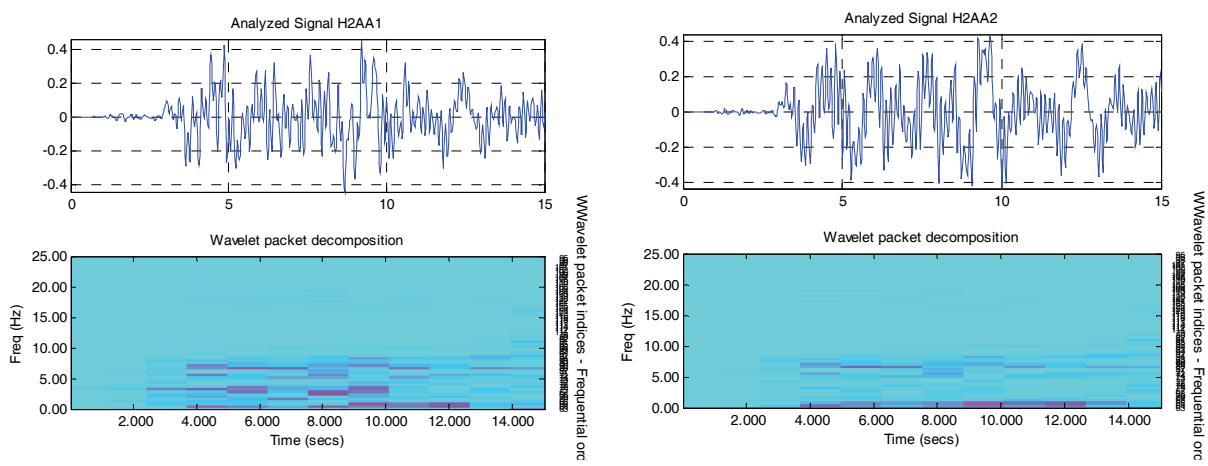

Şekil 33 - Analitik Modelin Mutlak İvme Parametresi Üzerinden Dalgacık Dönüşümleri 

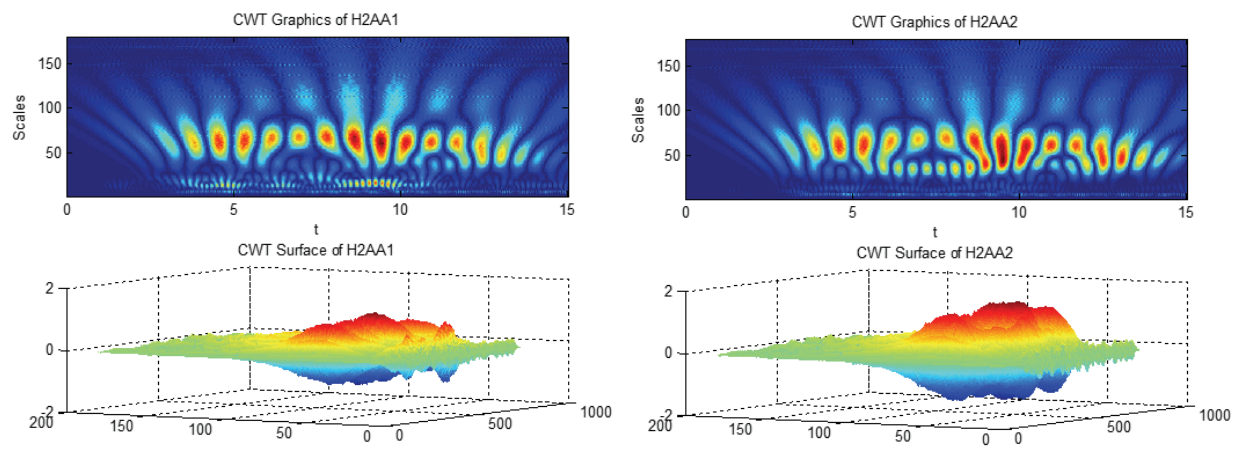

Şekil 33 - Analitik Modelin Mutlak İvme Parametresi Üzerinden Dalgacık Dönüşümleri (devam)

H2 yönlü mutlak ivme değerlerinde de benzer şekilde frekans kayıpları sürekli ve dalgacık paket dönüşümünde gözlemlenebilmektedir.
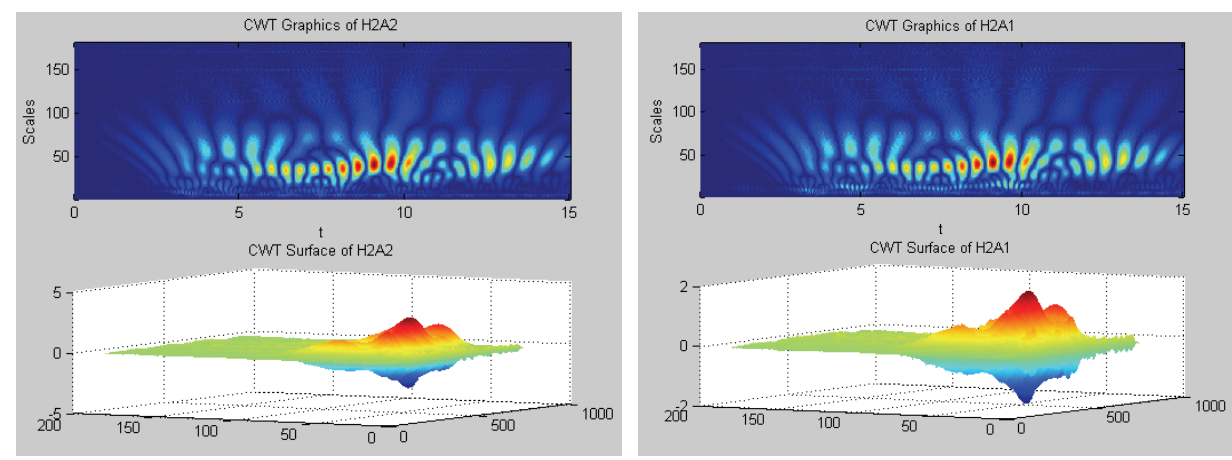

Şekil 34 - Analitik Modelin Relatif İvme Parametresi Üzerinden Dalgacık Dönüşümleri

H2 yönlü relatif ivme değerlerinde ise frekansın zamana göre düştüğünü gözlemleyebiliyoruz. Scale grafiğindeki yükselmeler frekansın tersi olduğundan frekans azalmasını ifade etmektedir.
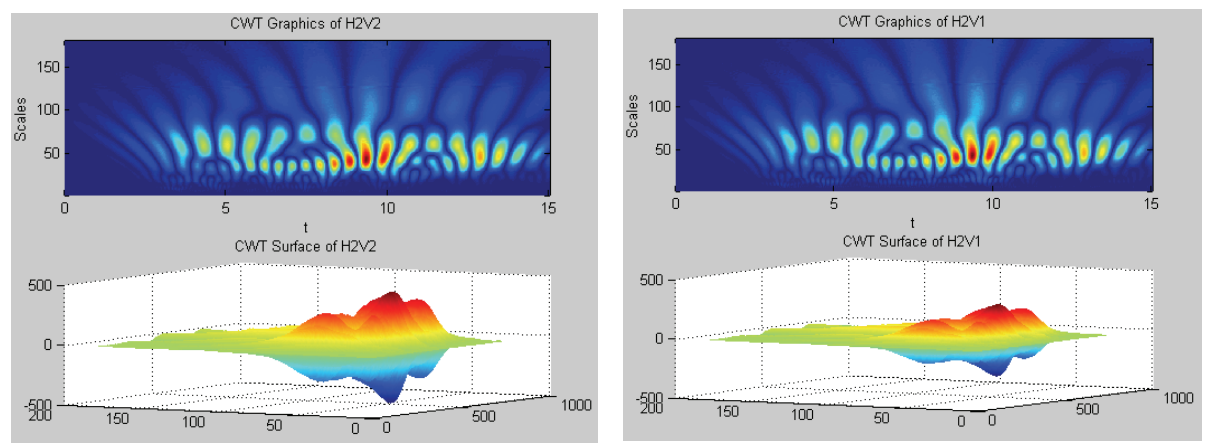

Şekil 35. Analitik Modelin Relatif İvme Parametresi Üzerinden Dalgacık Dönüşümleri 
H2 yönlü relatif hız değerlerinde ise frekansın zamana göre düştüğünü gözlemleyebiliyoruz. Scale grafiğindeki yükselmeler frekansın tersi olduğundan frekans azalmasını ifade etmektedir.
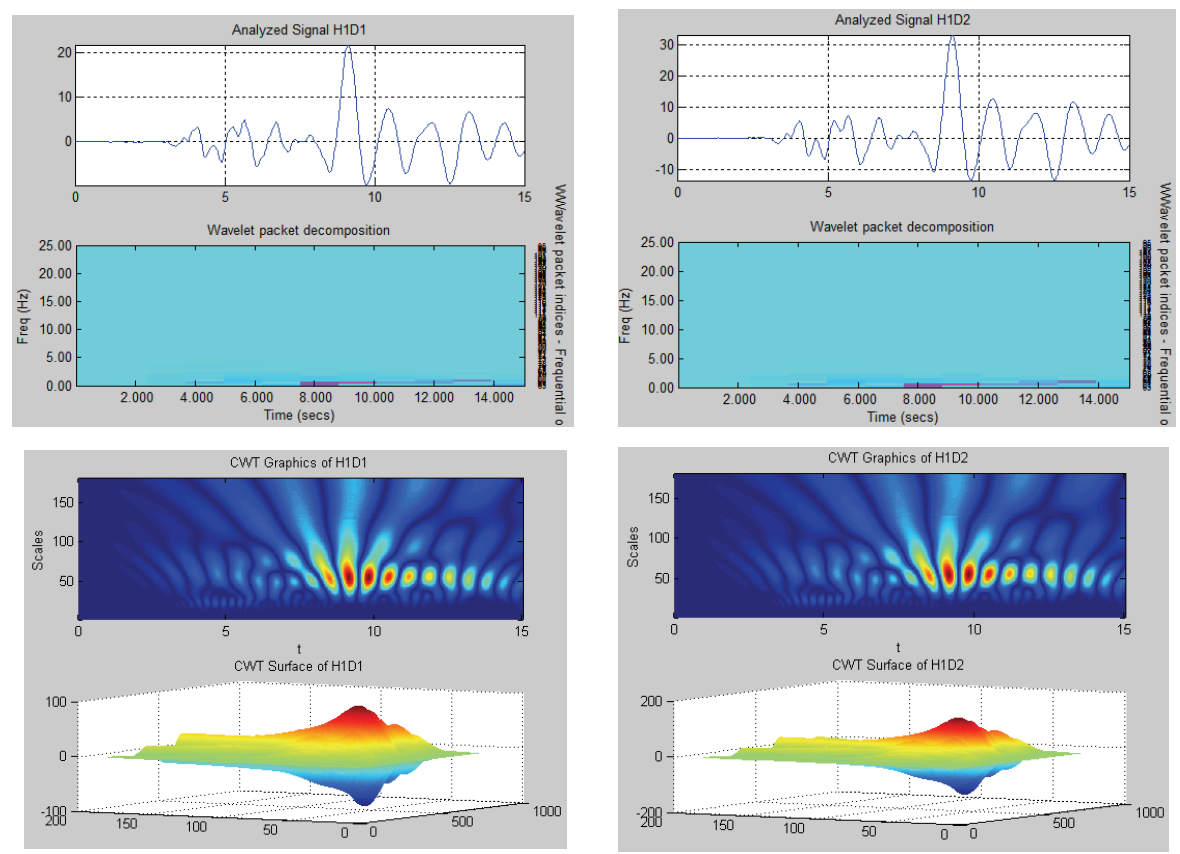

Şekil 36 - Analitik Modelin Relatif Deplasman Parametresi Üzerinden Dalgacık Dönüşümleri

Bu yapıdaki seçilen noktalar için relatif deplasman değerleri üzerinden herhangi bir farklılığa rastlanmamıştır.

\section{TARTIŞMA VE SONUÇLAR}

Bu çalışmada gösterildiği gibi Dalgacık (Wavelet) filtreleri yapı hasarını yakalamada etkin bir metot olarak kullanılabilmektedir. Hasar gören elemanlarla hasar görmeyen elemanlar arasındaki farklar dalgacık spektrumlarındaki zamanla değişen frekans muhteviyatı ve enerji yoğunluğundan anlaşılabilmektedir. Yapı türleri için deplasman ve ivme değerlerinin yanı sıra enerji parametreleri de anlık olarak izlenebilir ve yapı performansının kritik seviyeye gelmesi durumunda erken uyarı algoritmaları geliştirilebilir. Enerji değeri-frekans ilişkisi değişimleri, ivme ve hız değerlerinin zaman-frekans düzleminde değişimi Dalgacık dönüşümleriyle gözlenebilir hale gelmiştir. Frekans değişimi göreceli ivme grafiklerinde mutlak ivmeye göre daha başarılı bir şekilde tespit edilmektedir. Göreceli değerlendirme hasar tanılamada esas alınarak hızlı ve doğru karar ağacı oluşturulabilmektedir. İleride yapılacak çalışmalarla elde edilen sonuçların saha verileriyle doğrulanması sağlanabilir. Benzer şekilde hasarlı mevcut bir yapının Dalgacık analiz sonuçlarıyla nümerik modelinin güncellenmesi ise hale hazırda yapılagelmektedir. Beyen [25] analitik ve deneysel sonuçları bire-bir (auto correlation) ve çapraz (cross correlation) ilişkileriyle zaman-frekans ortamında 
çalışmış ve elde edilen Dalgacık transfer fonksiyonlarıyla yapı sağlığı değerlendirmesi ve model hatalarının iyileştirilmesini kat seviyesi hassaslığında uygulamıştır. Veri toplama ağının imkanları çerçevesinde kat taşıyıcı elemanları için de benzer durum değerlendirme ve nümerik model kalibrasyonlarının yapılabileceği belirtilmiştir.

Günümüzde ulaşılan teknoloji izleme, veri saklama-yönetme ve veri işlemeyi hızlandırmıştır. Yüksek işlem hızı ve saklama kapasitesi olan elektronik kartlarla algoritmalar sensör yanına yerleştirilmiş işlemci kartlarılla analiz edilebilmekte ve sadece karar vermede kullanılacak mühendislik parametre değerleri karar ağacının bulunduğu ortama transfer edilebilmektedir. Uçak ve uzay araçlarında standart olarak uygulanan deneysel modal analiz (DMA) inşaat mühendisliği yapılarında da uygulanmaya başlandığ 1 ve bu süreçle birlikte analizden yapı sağlığı izlemeye, durum tespitinden, hasar görebilirlik çalışmalarına ve köprülerde yapı işletme güvenliği gibi farklı uygulama alanlarında yapı üzerinde yürütülen testlerin artık sürekli izlemeye dönüştüğü Beyen'in [25] çalışmasında vurgulanmıştır. Kusunoki ve diğ. [26] tarafından Vincent Thomas köprüsünün 1987 Whitter, 1994 Northridge depremleri ve 2004 yılında kaydedilen iki çevrel titreşim tepki geçmişi Dalgacık dönüşümleriyle alt bileşenlerine ayrıştırılarak (decomposition) yapı sağlığı değerlendirmesi için yapısal davranış çalışılmıştır. Yapı sağlığ 1 izleme sistemleri içinde bir beton çatlak teşhis ağı Yan ve diğg. [27] tarafindan uygulanmıştır.

Dijital sensör teknolojisinde gelinen son on yılda sensör duyarlılığının ve veri kalitesinin (veri/gürültü oranının) yükselmesiyle örneğin kablosuz ve mikron boyutlarında Mikroelektro-mekanik sistem (MEMS) üç eksenli ivmeölçerler kaliteli sinyal verisiyle 50 ABD doları seviyelerinde bir maliyet ile yapı elemanı üzerinde ve birleşim noktalarında pasif gömülü izleme ağlarıyla kullanımı günümüzde mümkündür [28]. Çok yakın gelecekte düşük bakım ve uzayan servis ömürleriyle bu izleme ağları aktif izleme ağları olarak yapı sağlığ1 içinde kullanımları devam edecektir. Beraber kullanılan diğer farklı hasarsız izleme yöntemleriyle yapı sağlığında hasar teşhis tutarlılığı yükselmiştir. Laboratuvar şartlarında ölçekli yapı modelleriyle yapılan çalışmalar, yükselen sensör hassaslıkları, yonga içi işlem yazılımları ve düşen maliyetler sonuç bilgi eriştirme hızının çok yüksek olmasıyla yapı sağlığı kararlarının çok hızlı uygulanabileceği aktif yapı sağlığı izleme sistemlerinin mümkün olacağını göstermektedir [29]. Sensör üreticilerinin pazar yelpazelerine katılacak olan yeni kullanım sektörlerinin talepleri doğrultusunda arz-talep yapısı mevcut maliyetleri çok daha aşağıya çekecektir.

Çok katlı yapıların hızla çoğaldığı şehirlerimizde yapısal deprem güvenliğinin izlenmesi tasarım-imalat tutarlılığının yapı projelerinde son haliyle revize edilecek dinamik parametrelerin değerlendirilmesinden deprem riskinin ilgili yapı için sigortalanmasına kadar uygulama alanları oluşacak bir canlı yapı sağlığı izleme ve değerlendirme mümkündür. Bu çalışmada önerilen yöntemin eleman bazında gerçekçi sonuçlar elde edilecek düzeyde kullanılabilmesi için gerekli olan sensör sayısının günümüzün klasik uygulamalarının ötesinde olduğunu ve önerilen yöntem kullanılarak eleman bazlı gerçekçi hasar tahminlerinin yapılmasının şu an için pratik ve ekonomik açıdan uygulanabilirliğinin zor olduğunu belirtebiliriz. Ancak yaygın kullanıma geçildiğinde sensör maliyetlerinin azalması ve hesap yöntemlerinin gelişmesiyle birlikte Tanırcan ve diğ.'nin [29] yaptığ 1 çalışmada gösterildiği gibi maliyetler $1 / 50$ 'lere düşmekte ve uçak ve uzay mühendisliğindeki gibi inşaat mühendisliği yapılarının detaylı ve hassas olarak takip edilmesi mümkün olmaktadır. 


\section{Kaynaklar}

[1] Deng, X. and Wang, Q., Crack Detection Using Spatial Measurements and Wavelet. Int. J. Fracture, 9, 123-128, 1998.

[2] Worden, K. and Dulieu-Barton, J.M., An Overview of Intelligent Fault Detection in Systems and Structures. Structural Health Monitoring, 3(1), 85-98, 2004.

[3] Patsias, S. and Staszewski, W.J., Damage Detection Using Optical Measurements and Wavelets. Structural Health Monitoring, 1(1), 5-22, 2002.

[4] Yan, Y.J. and Yam, L.H., Detection of Delamination in Composite Plates Using Energy Spectrum of Structural Dynamic Responses Decomposed by Wavelet Analysis. Computers and Structures, 82, 347-358, 2004.

[5] Mallat, S., A Wavelet Tour of Signal Processing, 2nd edn, Academic Press, London, UK, 1999.

[6] Liew, K.M. and Wang, Q., Application of Wavelet Theory For Crack Identification in Structures. Journal of Engineering Mechanics, 124(2), 152-157, 1998.

[7] Park, G., Muntges, D.E. and Inman, D.J., Self-Monitoring and Self-Healing Jointed Structures. In: Damage Assessment Of Structures. Proceedings of the 4th International Conference on Damage Assessment of Structures, Cardiff, Wales, UK, June, Key Engineering Materials, Vols. 204-205, pp. 204-205, 2001.

[8] Douka, E., Loutridis, S. and Trochidis, A., Crack Identification in Beams Using Wavelet Analysis. International Journal of Solids and Structures, 40(13-14), 35573569, 2003.

[9] Gentile, A. and Messina, A., On The Continuous Wavelet Transforms Applied to Discrete Vibrational Data for Detecting Open Cracks in Damaged Beams. Int. Journal of Solids and Structures, 40(2), 295-315, 2003.

[10] Xu B., Wu Z., Yokoyama K., Harada T. and Chen G., A Soft Post-Earthquake Damage Identification Methodology Using Vibration Time Series. Smart Materials and Structures, 2005.

[11] Chang, C.C. and Chen, L.W., Damage Detection of a Rectangular Plate by Spatial Wavelet Based Approach. Applied Acoustics, 65, 819-832, 2004.

[12] Chang, C.C. and Chen, L.W., Detection of the Location and Size of Cracks in The Multiple Cracked Beam by Spatial Wavelet Based Approach. Mechanical Systems and Signal Processing, 19, 139-155, 2005.

[13] Kim, B.H., Park, T. and Voyiadjis, G.Z., Damage Estimation on Beam-Like Structures Using the Multi-Resolution Analysis. International Journal of Solids and Structures, 43, 4238-4257, 2006.

[14] Poudel, U.P., Fu, G.K. and Ye, H., Wavelet Transformation of Mode Shape Difference Function for Structural Damage Location Identification. Earthquake Engineering \& Structural Dynamics, 36, 1089-1107, 2007. 
[15] Ekici, S., Selcuk Y., \& Poyraz. M., Energy and Entropybased Feature Extraction for Locating Fault on Transmission Lines by Using Neural Network and Wavelet Packet Decomposition. Expert Systems with Applications 34.4, 2937-2944, 2008.

[16] Zhong, S. and Oyadiji, S.O., Detection of Cracks in Simply-Supported Beams by Continuous Wavelet Transform of Reconstructed Modal Data. Comput. Struct., 89(12), 127-148, 2011.

[17] Beyen K., Dalgacık Spektrumlarının Yap1 Sağlığı Durum Değerlendirme Çalışmalarında Önemi, 3. Türkiye Deprem Mühendisliği ve Sismoloji Konferansı, İzmir, Türkiye, 14-16 Ekim 2015.

[18] Beata Zima, Magdalena Rucka, Application of Wavelet Transform in Analysis of Guided Wave Propagation Signals For Damage Detection in A Steel Plate. Diagnostyka, Vol. 16, No. 2, 2015.

[19] H. Wang, and M. Noori and J. Zhang, A Wavelet-Energy Based Damage Identification Method for Steel Bridges. Conference Paper, June 2016.

[20] Mosbeh R. Kaloop and Jong Wan Hu, Damage Identification and Performance Assessment of Regular and Irregular Buildings Using Wavelet Transform Energy. Hindawi Publishing Corporation Advances in Materials Science and Engineering Volume 2016, Article ID 6027812, 11 pages, 2016.

[21] T. Kijewski-Correa and A. Kareem. 2007. Nonlinear Signal Analysis: Time-Frequency Perspectives, Journal of Engineering Mechanics, 238-245.

[22] T. Kijewski-Correa and A. Kareem. 2007. Performance of Wavelet Transform and Empirical Mode Decomposition in Extracting Signals Embedded in Noise, Journal of Engineering Mechanics, 849-852.

[23] Farrar, C.R., James, G.H., System Identification from Ambient Vibration Measurements on a Bridge. Journal of Sound and Vibration 205 (1), 1-18, 1997.

[24] Deprem Bölgelerinde Yapılacak Binalar Hakkında Yönetmelik, Bayındırlık ve İskan Bakanlığı, Ankara, 6 Mayıs 2007.

[25] Beyen K., Titreşim Verisiyle Güncellenmiş Sonlu Eleman Modeliyle Hasar Simülasyonu, Journal of the Faculty of Engineering and Architecture of Gazi University 32:2 (2017) 403-415.

[26] Kusunoki K., Elgamal A., Teshigawara M., Conte J. P., Evaluation of Structural Condition Using Wavelet Transforms, The 14th World Conference on Earthquake Engineering, October 12-17, 2008, Beijing, China.

[27] Yan S., Ma H., Li P., Song G., Wu J., Development and Application of a Structural Health Monitoring System Based on Wireless Smart Aggregates, Sensors, 17,1641,2017; doi:10.3390/s17071641.

[28] Jerome P. L., Aaron P., Kincho, H., Thomas, W. K., Kiremidjian, A. S., Ed, C., 'Design of Piezoresistive MEMS-Based Accelerometer for Integration with Wireless Sensing Unit for Structural Monitoring,, DOI: 10.1061/(ASCE)0893-1321(2003)16:3(1), Journal of Aerospace Engineering - ASCE / July 2003. 
Yapıların Zaman-Frekans Ortamında Dalgacık Dönüşümü Metoduyla Hasar Analizleri

[29] Tanırcan G., Alçık H., Beyen K., Reliability of MEMS Accelerometers for Instrumental Intensity Mapping of Earthquakes, Annals of Geophysics, 60, Supplement to 6, SE673,2017, doi:10.4401/ag-7501. 